\title{
LEVEL II SCOUR ANALYSIS FOR BRIDGE 37 (TOWNTH00290037) on TOWN HIGHWAY 29, crossing MILL BROOK, TOWNSHEND, VERMONT
}

Open-File Report 98-152

Prepared in cooperation with

VERMONT AGENCY OF TRANSPORTATION

and

FEDERAL HIGHWAY ADMINISTRATION

U.S. Department of the Interior

U.S. Geological Survey






\section{LEVEL II SCOUR ANALYSIS FOR BRIDGE 37 (TOWNTH00290037) on TOWN HIGHWAY 29, crossing MILL BROOK, TOWNSHEND, VERMONT \\ By RONDA L. BURNS and LAURA MEDALIE}

U.S. Geological Survey Open-File Report 98-152

Prepared in cooperation with

VERMONT AGENCY OF TRANSPORTATION

and

FEDERAL HIGHWAY ADMINISTRATION 


\title{
U.S. DEPARTMENT OF THE INTERIOR BRUCE BABBITT, Secretary
}

\author{
U.S. GEOLOGICAL SURVEY
}

Thomas J. Casadevall, Acting Director

For additional information write to:

District Chief

U.S. Geological Survey 361 Commerce Way

Pembroke, NH 03275-3718
Copies of this report may be purchased from:

U.S. Geological Survey

Branch of Information Services

Open-File Reports Unit

Box 25286

Denver, CO 80225-0286 


\section{CONTENTS}

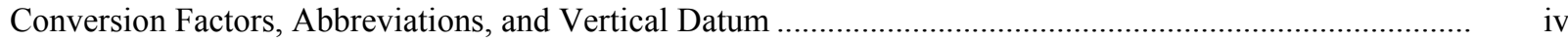

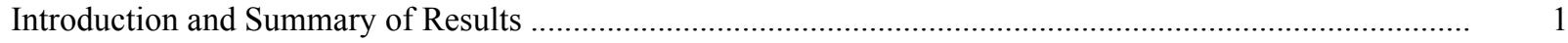

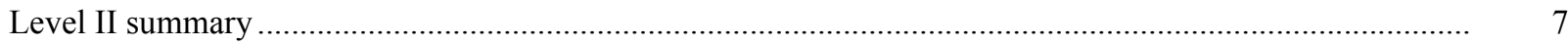

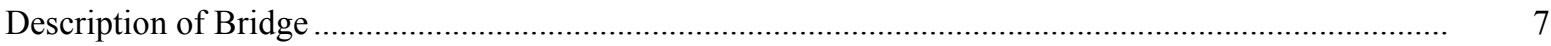

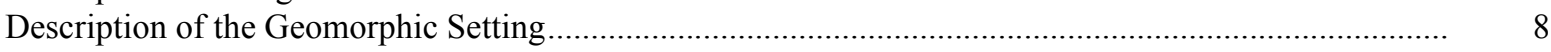

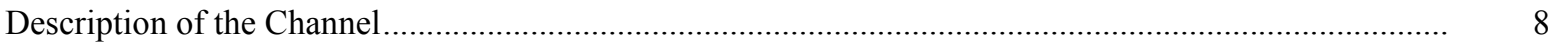

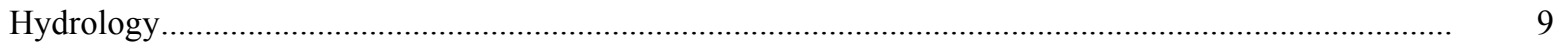



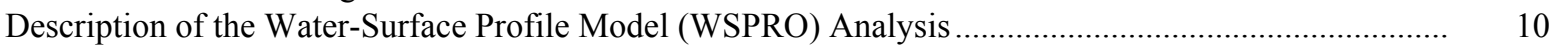

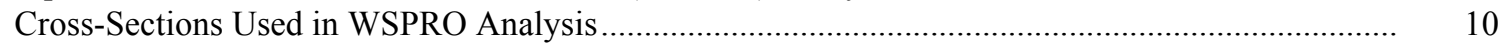

Data and Assumptions Used in WSPRO Model ........................................................................ 11



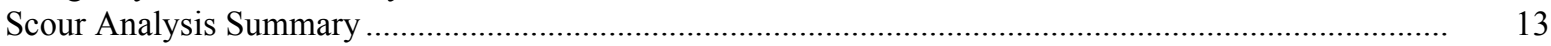

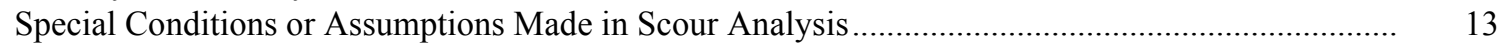

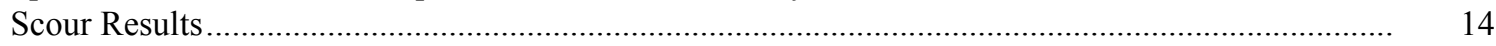

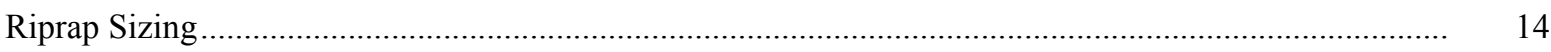

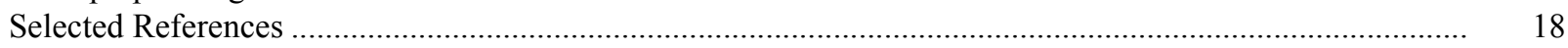

Appendices:

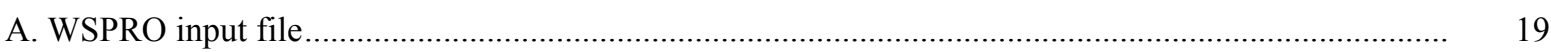

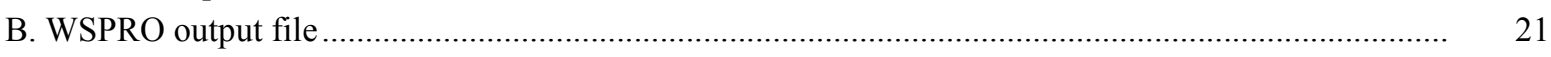



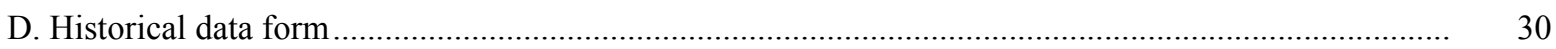

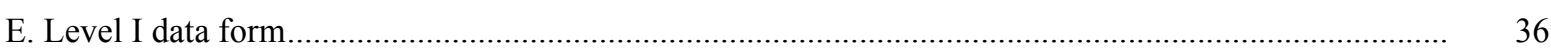

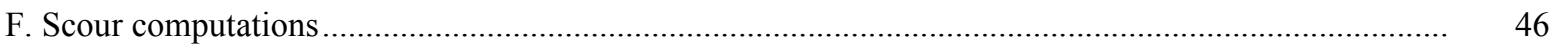

\section{FIGURES}

1. Map showing location of study area on USGS 1:25,000 scale map

2. Map showing location of study area on Vermont Agency of Transportation town highway map

3. Structure TOWNTH00290037 viewed from upstream (August 14, 1996)

4

4. Downstream channel viewed from structure TOWNTH00290037 (August 14, 1996)........................... 5

5. Upstream channel viewed from structure TOWNTH00290037 (August 14, 1996)................................. 6



7. Water-surface profiles for the 100- and 500-year discharges at structure

TOWNTH00290037 on Town Highway 29, crossing Mill Brook,

Townshend, Vermont.

8. Scour elevations for the 100- and 500-year discharges at structure

TOWNTH00290037 on Town Highway 29, crossing Mill Brook,

Townshend, Vermont.

\section{TABLES}

1. Remaining footing/pile depth at abutments for the 100-year discharge at structure

TOWNTH00290037 on Town Highway 29, crossing Mill Brook,

Townshend, Vermont.

2. Remaining footing/pile depth at abutments for the 500-year discharge at structure

TOWNTH00290037 on Town Highway 29, crossing Mill Brook,

Townshend, Vermont. 


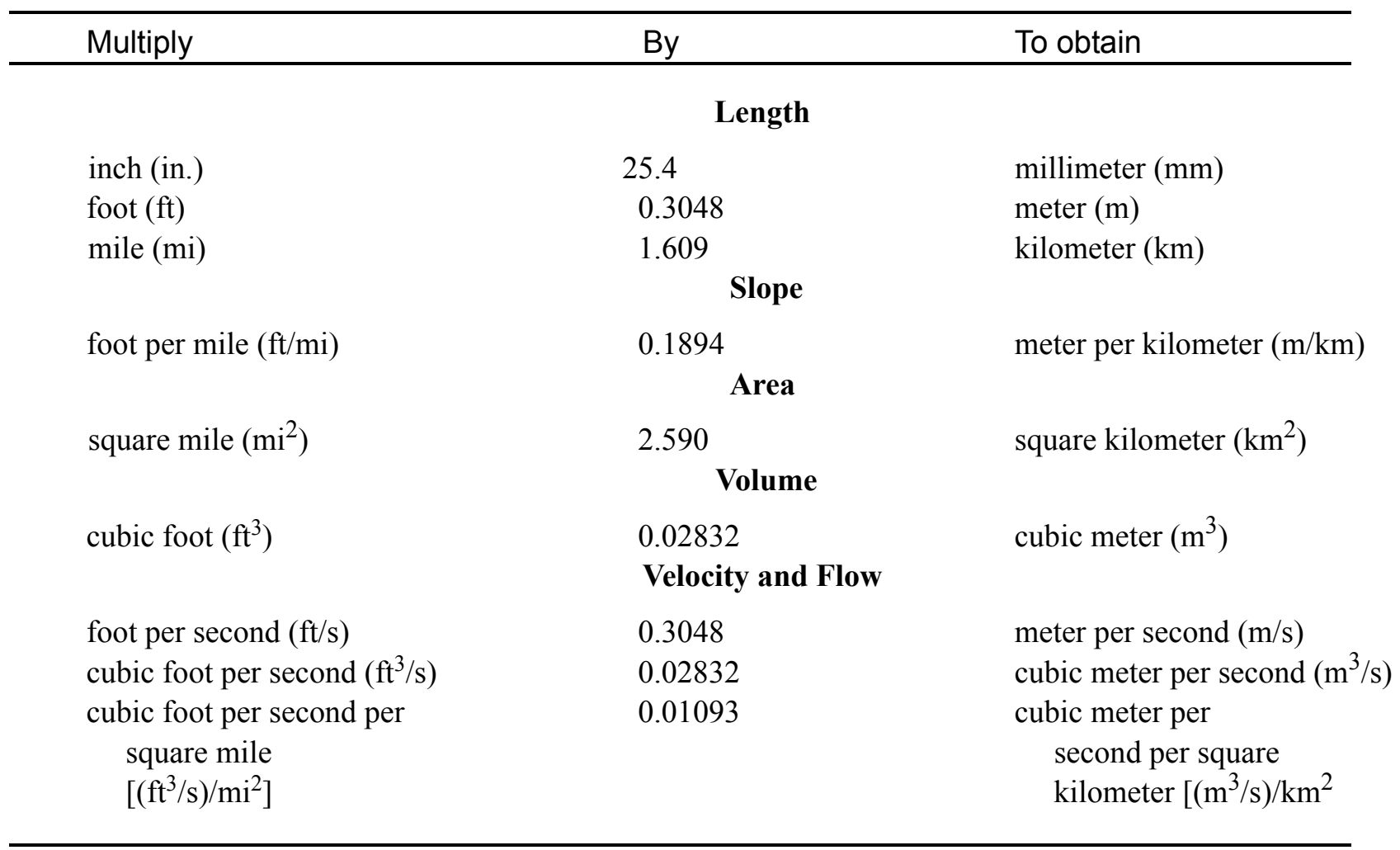

\section{OTHER ABBREVIATIONS}

$\begin{array}{lrlr}\mathrm{BF} & \text { bank full } & \text { LWW } & \text { left wingwall } \\ \mathrm{cfs} & \text { cubic feet per second } & \text { Max } & \text { maximum } \\ \mathrm{D}_{50} & \text { median diameter of bed material } & \text { MC } & \text { main channel } \\ \mathrm{DS} & \text { downstream } & \text { RAB } & \text { right abutment } \\ \mathrm{elev} & \text { elevation } & \text { RABUT } & \text { face of right abutment } \\ \mathrm{f} / \mathrm{p} & \text { flood plain } & \text { RB } & \text { right bank } \\ \mathrm{ft} & \text { square feet } & \text { ROB } & \text { right overbank } \\ \mathrm{ft} / \mathrm{ft} & \text { feet per foot } & \text { RWW } & \text { right wingwall } \\ \mathrm{FEMA} & \text { Federal Emergency Management Agency } & \text { TH } & \text { town highway } \\ \mathrm{FHWA} & \text { Federal Highway Administration } & \text { UB } & \text { under bridge } \\ \mathrm{JCT} & \text { junction } & \text { US } & \text { upstream } \\ \text { LAB } & \text { left abutment } & \text { USGS } & \text { United States Geological Survey } \\ \text { LABUT } & \text { face of left abutment } & \text { VTAOT } & \text { Vermont Agency of Transportation } \\ \text { LB } & \text { left bank } & \text { WSPRO } & \text { water-surface profile model } \\ \text { LOB } & \text { left overbank } & \text { yr } & \text { year }\end{array}$

In this report, the words "right" and "left" refer to directions that would be reported by an observer facing downstream. Sea level: In this report, "sea level" refers to the National Geodetic Vertical Datum of 1929-- a geodetic datum derived from a general adjustment of the first-order level nets of the United States and Canada, formerly called Sea Level Datum of 1929.

In the appendices, the above abbreviations may be combined. For example, USLB would represent upstream left bank. 


\title{
LEVEL II SCOUR ANALYSIS FOR BRIDGE 37 (TOWNTH00290037) ON TOWN HIGHWAY 29, CROSSING MILL BROOK, TOWNSHEND, VERMONT
}

\author{
By Ronda L. Burns and Laura Medalie
}

\section{INTRODUCTION AND SUMMARY OF RESULTS}

This report provides the results of a detailed Level II analysis of scour potential at structure TOWNTH00290037 on Town Highway 29 crossing Mill Brook, Townshend, Vermont (figures 1-8). A Level II study is a basic engineering analysis of the site, including a quantitative analysis of stream stability and scour (FHWA, 1993). Results of a Level I scour investigation also are included in Appendix E of this report. A Level I investigation provides a qualitative geomorphic characterization of the study site. Information on the bridge, gleaned from Vermont Agency of Transportation (VTAOT) files, was compiled prior to conducting Level I and Level II analyses and is found in appendix D.

The site is in the New England Upland section of the New England physiographic province in southeastern Vermont. The $13.9-\mathrm{mi}^{2}$ drainage area is in a predominantly rural and forested basin. In the vicinity of the study site, the surface cover is forest upstream of the bridge. Downstream of the bridge the surface cover is pasture on the left bank and shrub and brushland on the right bank.

In the study area, Mill Brook has an incised, sinuous channel with a slope of approximately $0.01 \mathrm{ft} / \mathrm{ft}$, an average channel top width of $53 \mathrm{ft}$ and an average bank height of $8 \mathrm{ft}$. The channel bed material ranges from gravel to boulder with a median grain size $\left(\mathrm{D}_{50}\right)$ of 70.0 $\mathrm{mm}(0.230 \mathrm{ft})$. The geomorphic assessment at the time of the Level I and Level II site visit on August 14,1996, indicated that the reach was laterally unstable. There are large cutbanks and point bars upstream and downstream of the bridge. There is also moderate fluvial erosion on the upstream left bank and downstream right bank.

The Town Highway 29 crossing of Mill Brook is a 33-ft-long, one-lane bridge consisting of one 30-foot steel-girder span (Vermont Agency of Transportation, written communication, April 7, 1995). The opening length of the structure parallel to the bridge face is $24.8 \mathrm{ft}$. The bridge is supported by vertical, concrete abutments with wingwalls, the downstream left wingwall, however, is "laid-up" stone. The channel is skewed approximately 45 degrees to the opening while the computed opening-skew-to-roadway is 25 degrees. 
A scour hole $1.0 \mathrm{ft}$ deeper than the mean thalweg depth was observed along the right abutment during the Level I assessment. This scour hole continues downstream along the right bank and deepens to $1.5 \mathrm{ft}$ deeper than the mean thalweg. The scour protection measures at the site included type-2 stone fill (less than 36 inches diameter) along the upstream left and right banks and along the upstream right wingwall. Type-3 stone fill (less than 48 inches diameter) was along the downstream right wingwall and downstream right bank and a short stone wall is on the downstream left bank. Additional details describing conditions at the site are included in the Level II Summary and appendices D and E.

Scour depths and recommended rock rip-rap sizes were computed using the general guidelines described in Hydraulic Engineering Circular 18 (Richardson and Davis, 1995) for the 100- and 500-year discharges. In addition, the incipient roadway-overtopping discharge was determined and analyzed as another potential worst-case scour scenario. Total scour at a highway crossing is comprised of three components: 1) long-term streambed degradation; 2) contraction scour (due to accelerated flow caused by a reduction in flow area at a bridge) and; 3 ) local scour (caused by accelerated flow around piers and abutments). Total scour is the sum of the three components. Equations are available to compute depths for contraction and local scour and a summary of the results of these computations follows.

Contraction scour for all modelled flows ranged from 0.0 to $2.1 \mathrm{ft}$. The worst-case contraction scour occurred at the 500-year discharge. Left abutment scour ranged from 6.7 to $8.7 \mathrm{ft}$. The worst-case left abutment scour occurred at the incipient roadway-overtopping discharge. Right abutment scour ranged from 7.8 to $9.5 \mathrm{ft}$. The worst-case right abutment scour occurred at the 500-year discharge. Additional information on scour depths and depths to armoring are included in the section titled "Scour Results". Scoured-streambed elevations, based on the calculated scour depths, are presented in tables 1 and 2. A crosssection of the scour computed at the bridge is presented in figure 8. Scour depths were calculated assuming an infinite depth of erosive material and a homogeneous particle-size distribution.

It is generally accepted that the Froehlich equation (abutment scour) gives "excessively conservative estimates of scour depths" (Richardson and Davis, 1995, p. 46). Usually, computed scour depths are evaluated in combination with other information including (but not limited to) historical performance during flood events, the geomorphic stability assessment, existing scour protection measures, and the results of the hydraulic analyses. Therefore, scour depths adopted by VTAOT may differ from the computed values documented herein. 


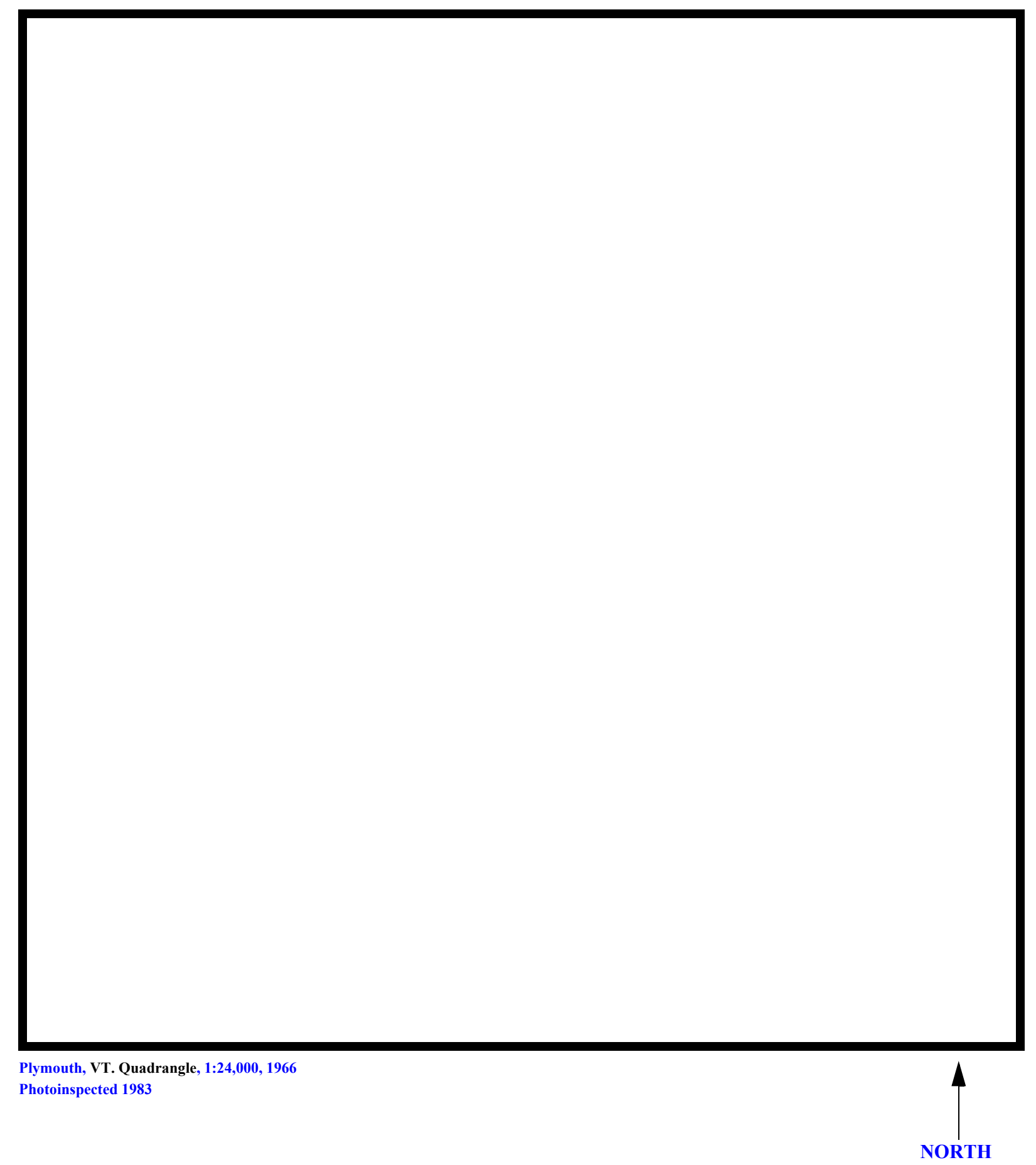

Figure 1. Location of study area on USGS 1:24,000 scale map. 
Figure 2. Location of study area on Vermont Agency of Transportation town highway map. 

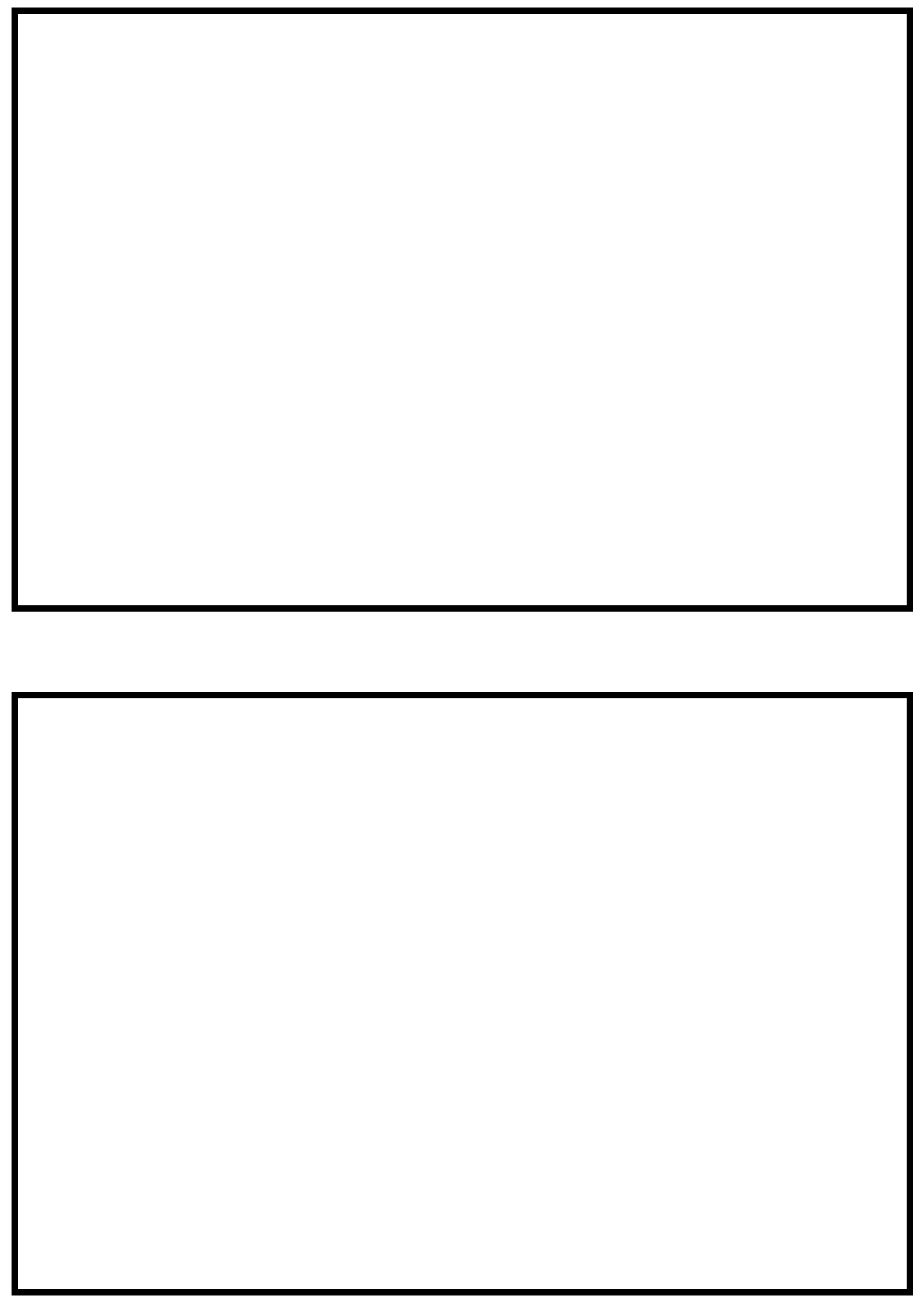

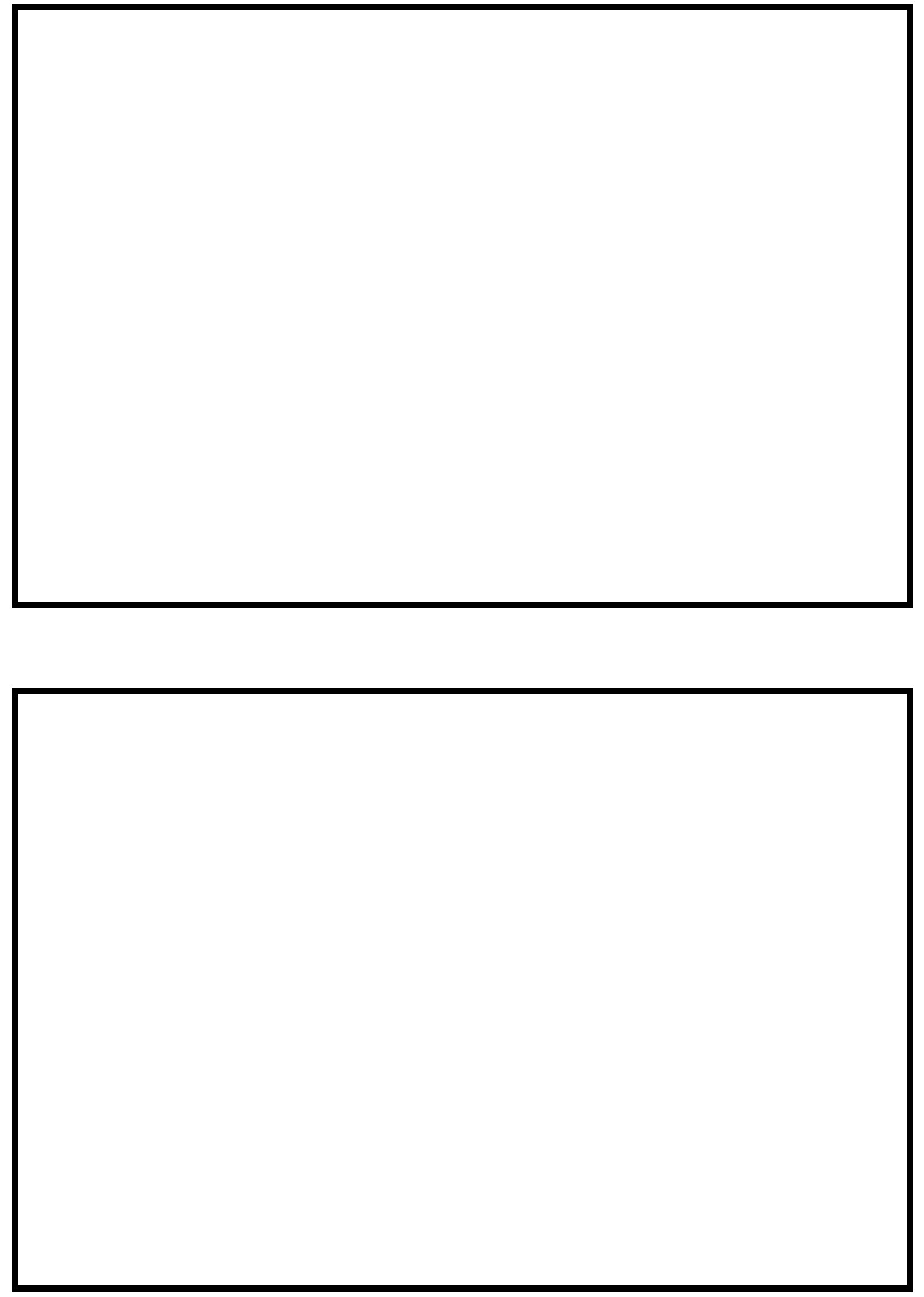


\section{LEVEL II SUMMARY}

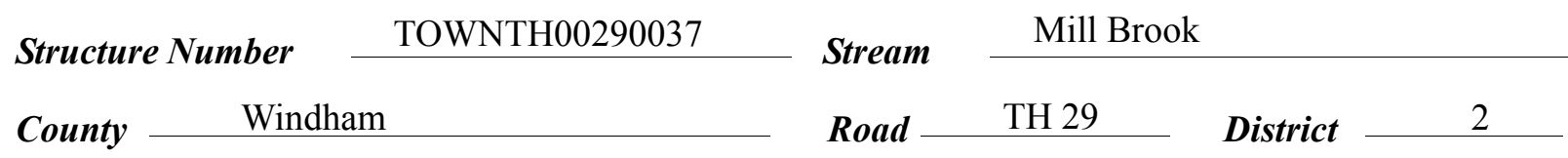

\section{Description of Bridge}

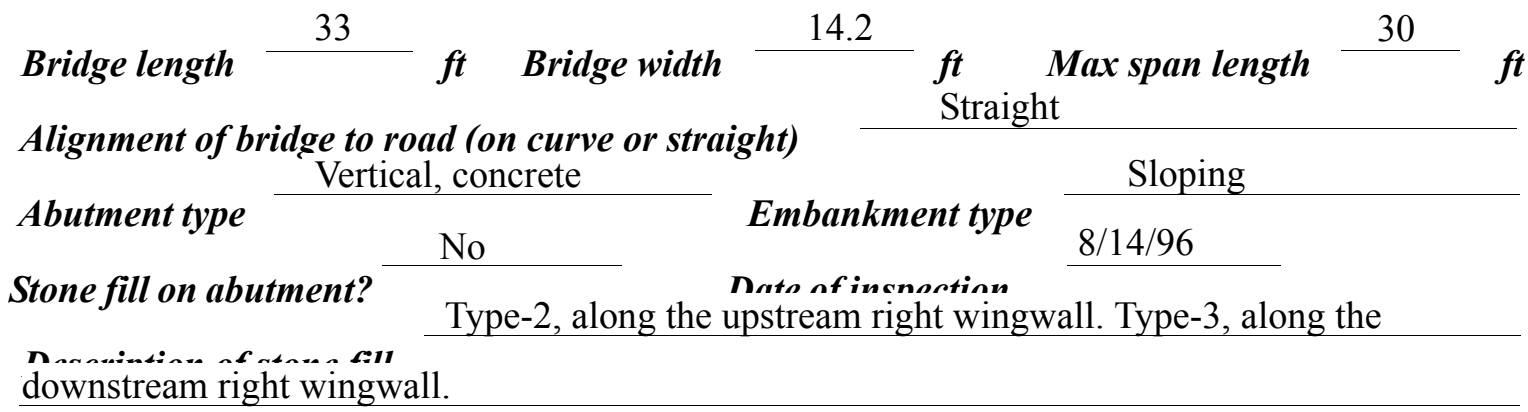

Abutments and wingwalls are concrete, except for the downstream left wingwall which is "laid-up" stone. There is a one foot deep scour hole along the right abutment.

Yes

$$
\text { Angle }
$$

There is a moderate channel bend through the bridge. The scour hole has developed in the location where the flow impacts the right abutment.

Debris accumulation on bridge at time of Level I or Level II site visit:

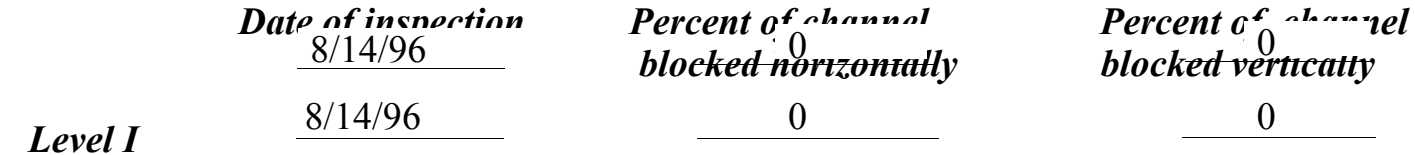

Level II

Moderate. There are some small scattered pieces of debris on the upstream banks.

Potential for debris

None as of 8/14/96.

Doscriho any, foaturos noar ar at tho hridos that mav, affoct flou, (includo ahsorvation dato) 


\section{Description of the Geomorphic Setting}

General topography The channel is located within a low relief valley with a narrow flood plain.

Geomorphic conditions at bridge site: downstream (DS), upstream (US)

Date of inspection $\quad 8 / 14 / 96$

DS left: $\quad$ Narrow flood plain

DS right: $\quad$ Moderately sloped overbank

US left: $\quad$ Steep valley wall

US right: $\quad$ Moderately sloped overbank

\section{Description of the Channel}

\begin{tabular}{|c|c|c|c|}
\hline \multirow[b]{2}{*}{ Average top width } & 53 & \multirow[b]{2}{*}{ Average depth } & \multirow[b]{2}{*}{ Sand/Gravel ${ }^{\boldsymbol{f}}$} \\
\hline & $\begin{array}{c}\boldsymbol{f t}_{\boldsymbol{t}} \\
\text { Gravel/Cobbles }\end{array}$ & & \\
\hline Predominant bed mo & & Bank material & Sinuous and laterally \\
\hline
\end{tabular}

unstable with semi-älluvial channel boundaries and wide point $\ddot{\text { bars. }}$

$8 / 14 / 96$

Vegetative co ${ }^{\text {Few }}$ trees and short grass

DS left: $\quad$ Shrubs and brush

DS right: $\quad$ Trees and brush

US left: $\quad$ Trees and brush with a lawn on the overbank

US right:

No

Do banks appear stable? There are large point bars and cut-banks upstream and downstream of the bridge as of $8 / 14 / 96$.
date of omservatton.

None as of 8/14/96.

Describe any obstructions in channel and date of observation. 


\title{
Hydrology
}

Drainage area $\frac{13.9}{\boldsymbol{m i}^{2}}$

Percentage of drainage area in physiographic provinces: (approximate)

Physiographic province/section New England/New England Upland
Percent of drainage area 100

\begin{abstract}
Is drainage area considered rural or urban?
Rural None.

urbanization:-

Describe any significant
\end{abstract}

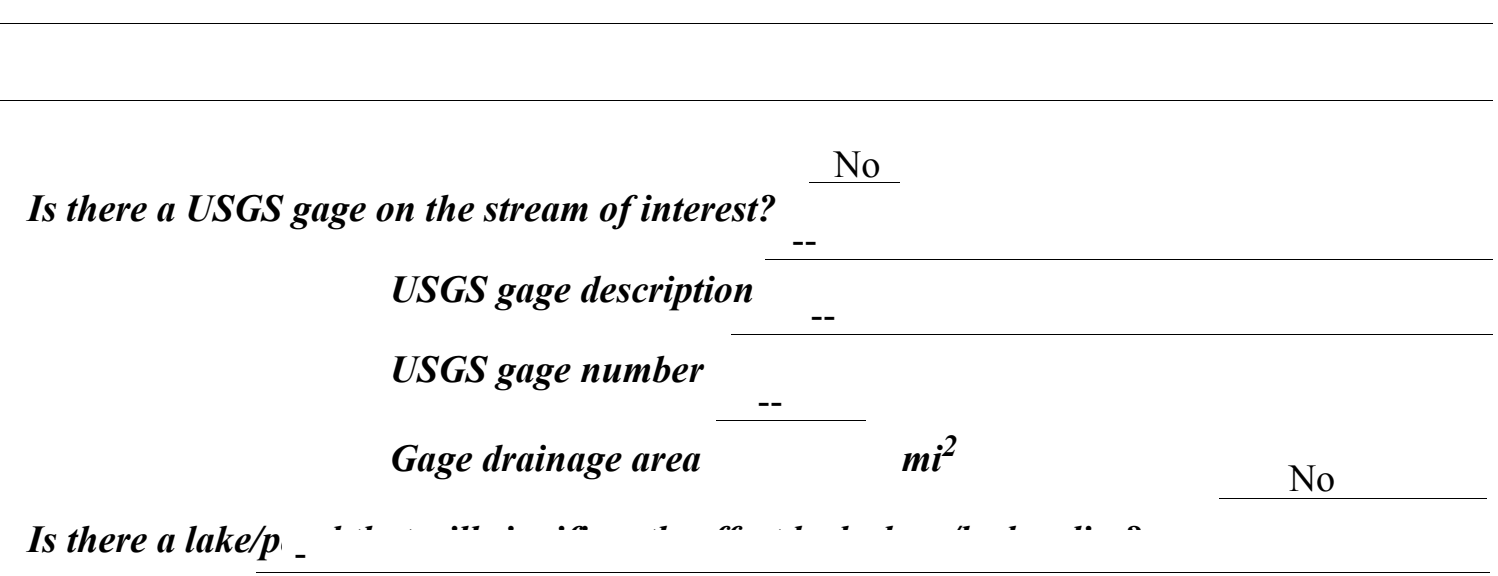

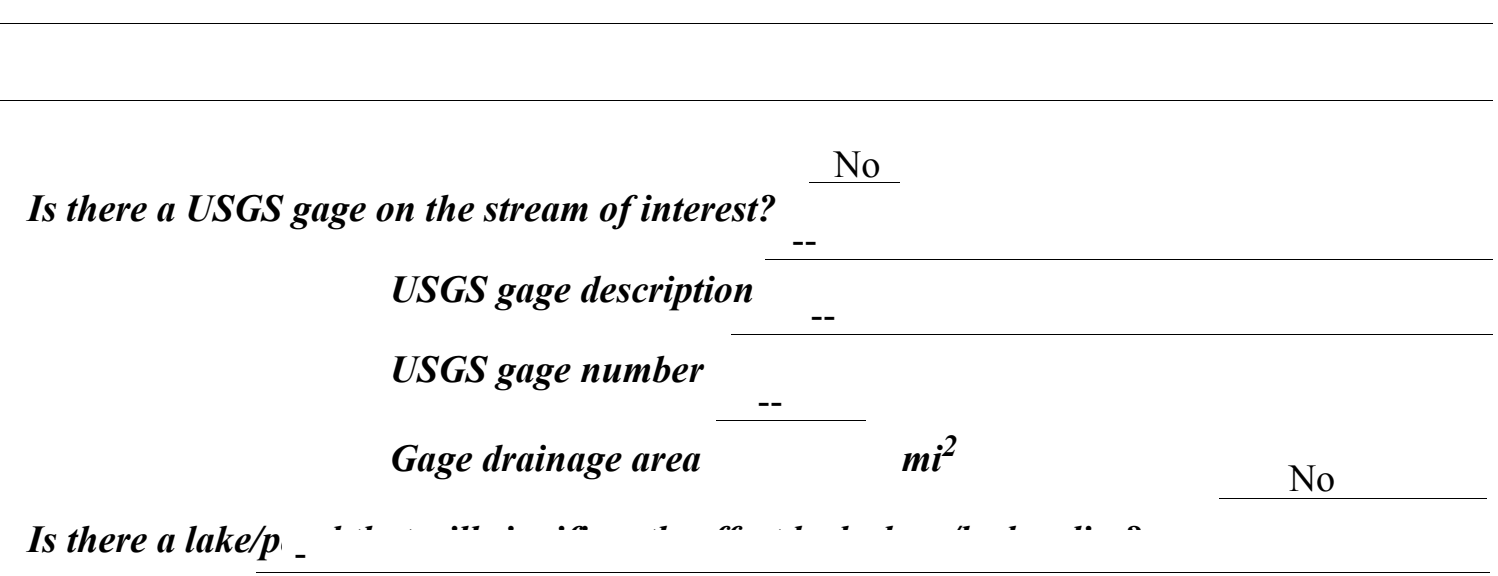

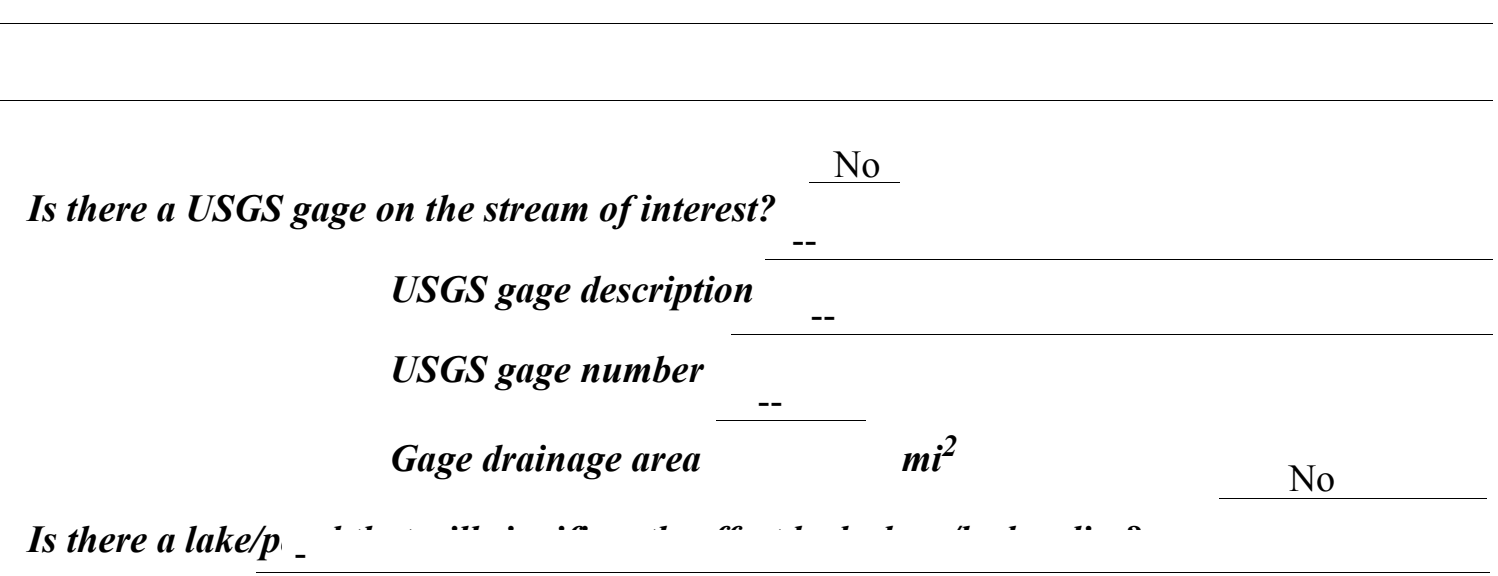

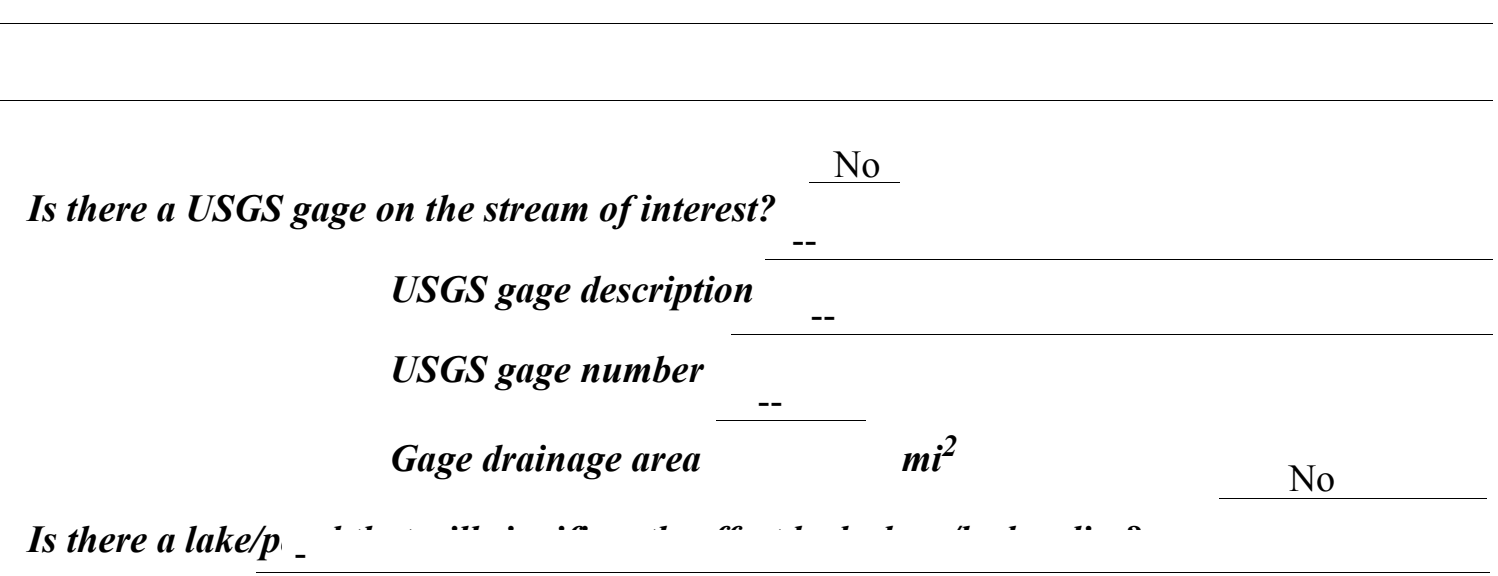

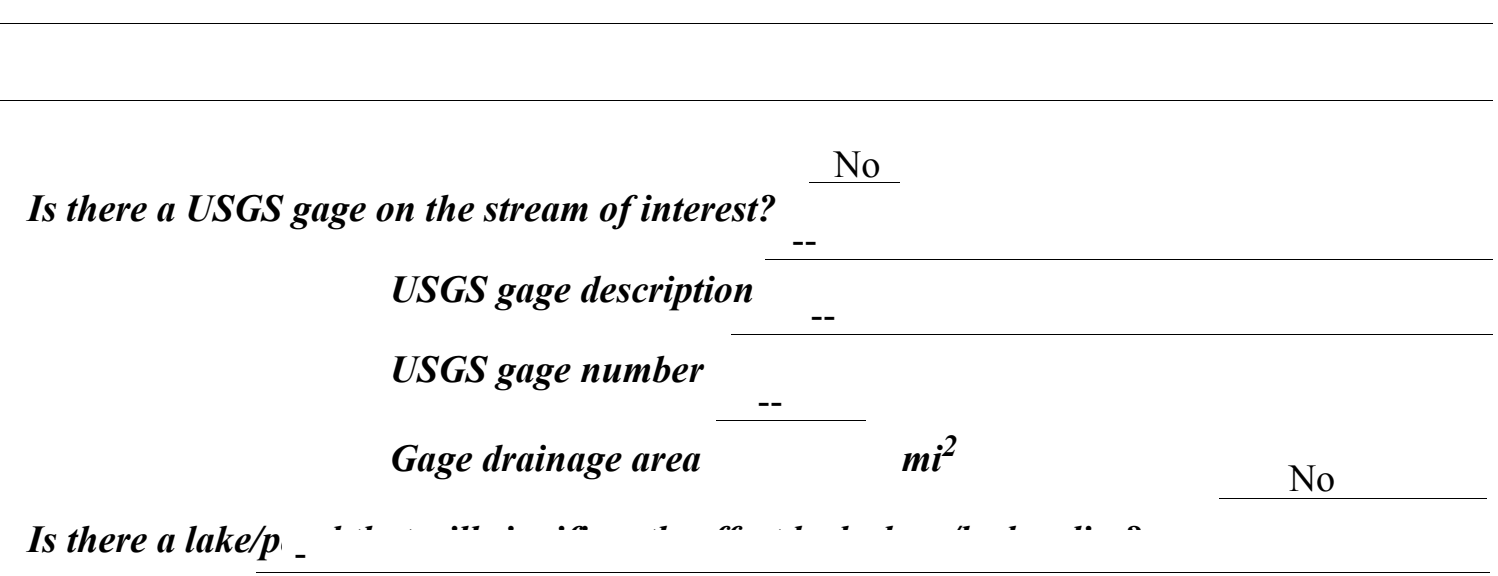

Is there a lake/p -

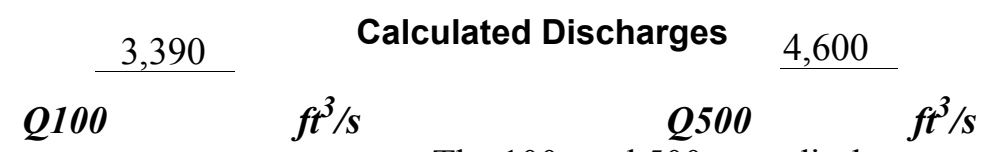

The 100- and 500-year discharges are based on a

drainage area relationship [(13.9/13.3)exp 0.67] with bridge number 18 in Townshend. Bridge number 18 crosses Mill Brook upstream of this site and has flood frequency estimates available from the VTAOT database (Vermont Agency of Transportation, written communication, May 1995). The drainage area above bridge number 18 is 13.3 square miles. The values used were within a range defined by flood frequency curves developed from several empirical methods (Benson, 1962; Johnson and Tasker, 1974; FHWA, 1983; Potter, 1957a\&b; Talbot, 1887). 


\section{Description of the Water-Surface Profile Model (WSPRO) Analysis}

Datum for WSPRO analysis (USGS survey, sea level, VTAOT plans)

USGS survey

Datum tie between USGS survey and VTAOT plans

None

Description of reference marks used to determine USGS datum. $\quad$ RM1 is a chiseled X on top of the upstream end of the right abutment (elev. $495.46 \mathrm{ft}$, arbitrary survey datum). RM2 is a chiseled X on top of the downstream end of the left abutment (elev. $497.28 \mathrm{ft}$, arbitrary survey

datum).

\section{Cross-Sections Used in WSPRO Analysis}

\begin{tabular}{|c|c|c|c|}
\hline${ }^{1}$ Cross-section & $\begin{array}{c}\text { Section } \\
\text { Reference } \\
\text { Distance } \\
\text { (SRD) in feet }\end{array}$ & $\begin{array}{c}{ }^{2} \text { Cross-section } \\
\text { development }\end{array}$ & Comments \\
\hline EXITX & -30 & 1 & Exit section \\
\hline FULLV & 0 & 2 & $\begin{array}{l}\text { Downstream Full-valley } \\
\text { section (Templated from } \\
\text { EXITX) }\end{array}$ \\
\hline BRIDG & 0 & 1 & Bridge section \\
\hline RDWAY & 15 & 1 & Road Grade section \\
\hline APTEM & 48 & 1 & $\begin{array}{l}\text { Approach section as sur- } \\
\text { veyed (Used as a tem- } \\
\text { plate) }\end{array}$ \\
\hline APPRO & 52 & 2 & $\begin{array}{l}\text { Modelled Approach sec- } \\
\text { tion (Templated from } \\
\text { APTEM) }\end{array}$ \\
\hline
\end{tabular}

${ }^{1}$ For location of cross-sections see plan-view sketch included with Level I field form, Appendix E. For more detail on how cross-sections were developed see WSPRO input file. 


\section{Data and Assumptions Used in WSPRO Model}

Hydraulic analyses of the reach were done by use of the Federal Highway Administration's WSPRO step-backwater computer program (Shearman and others, 1986, and Shearman, 1990). The analyses reported herein reflect conditions existing at the site at the time of the study. Furthermore, in the development of the model it was necessary to assume no accumulation of debris or ice at the site. Results of the hydraulic model are presented in the Bridge Hydraulic Summary, appendix B, and figure 7.

Channel roughness factors (Manning's “ $n$ ”) used in the hydraulic model were estimated using field inspections at each cross section following the general guidelines described by Arcement and Schneider (1989). Final adjustments to the values were made during the modelling of the reach. Channel " $\mathrm{n}$ " values for the reach ranged from 0.045 to 0.060 , and overbank " $n$ " values ranged from 0.040 to 0.080 .

Normal depth at the exit section (EXITX) was assumed as the starting water surface. This depth was computed by use of the slope-conveyance method outlined in the user's manual for WSPRO (Shearman, 1990). The slope used was $0.0056 \mathrm{ft} / \mathrm{ft}$, which was estimated from surveyed thalweg points downstream of the bridge.

The surveyed approach section (APTEM) was moved along the approach channel slope $(0.0345 \mathrm{ft} / \mathrm{ft})$ to establish the modelled approach section (APPRO), one bridge length upstream of the upstream face as recommended by Shearman and others (1986). This location provides a consistent method for determining scour variables. 


\section{Bridge Hydraulics Summary}

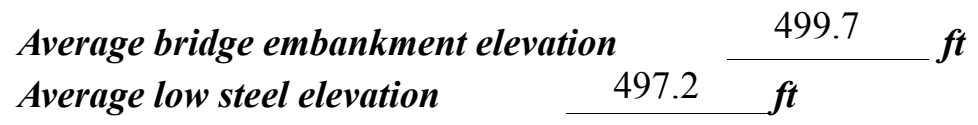

$$
\text { 100-year discharge } \quad 3,390 \quad \mathrm{ft}^{3} / \mathrm{s}
$$

Water-surface elevation in bridge opening $\quad 497.2 \quad f t$

Road overtopping? ___ Yes Discharge over road _ $1,170,3 / s$

\begin{tabular}{llc} 
Area of flow in bridge opening & $205 \quad \boldsymbol{f t}^{2}$ \\
\cline { 2 - 3 } Average velocity in bridge opening & $11.0 \quad \mathrm{ft} / \mathrm{s}$
\end{tabular}

$\begin{array}{llll}\text { Maximum WSPRO tube velocity at bridge } & 17.0 \mathrm{ft} / \mathrm{s}\end{array}$

Water-surface elevation at Approach section with bridge $\quad 500.7$

Water-surface elevation at Approach section without bridge $\quad \overline{495.7}$

Amount of backwater caused by bridge $\quad 5.0 \quad$ it

500-year discharge $\quad 4,600 \quad \mathrm{ft}^{3} / \mathrm{s}$

Water-surface elevation in bridge opening $\quad 497.4 \mathrm{ft}$

Road overtopping? ___ Yes Discharge over road _ $2,150, \ldots$

Area of flow in bridge opening $\quad 206 \quad \mathrm{ft}^{2}$

Average velocity in bridge opening $11.5 \mathrm{ft} / \mathrm{s}$

Maximum WSPRO tube velocity at bridge 15.2 's

Water-surface elevation at Approach section with bridge 501.3

Water-surface elevation at Approach section without bridge $\quad 496.8$

Amount of backwater caused by bridge $\quad 4.5, t$

Incipient overtopping discharge $\quad 1,770 \mathrm{ft}^{3} / \mathrm{s}$

Water-surface elevation in bridge opening $497.4 \quad t$

\begin{tabular}{llcl} 
Area of flow in bridge opening & 206 & $\boldsymbol{f t}^{2}$ \\
\cline { 2 - 3 } Average velocity in bridge opening & $8.6 \quad f t / s$
\end{tabular}

Maximum WSPRO tube velocity at bridge $11.4 \mathrm{ft} / \mathrm{s}$

Water-surface elevation at Approach section with bridge

Water-surface elevation at Approach section without bridge

498.9

Amount of backwater caused by bridge $\quad 4.8$, t 


\section{Scour Analysis Summary}

\section{Special Conditions or Assumptions Made in Scour Analysis}

Scour depths were computed using the general guidelines described in Hydraulic Engineering Circular 18 (Richardson and Davis, 1995). Scour depths were calculated assuming an infinite depth of erosive material and a homogeneous particle-size distribution. The results of the scour analyses for the 100- and 500-year discharges are presented in tables 1 and 2 and the scour depths are shown graphically in figure 8.

At this site, the 100-year, 500-year, and incipient roadway-overtopping discharges resulted in unsubmerged orifice flow. Contraction scour at bridges with orifice flow is best estimated by use of the Chang pressure-flow scour equation (oral communication, J. Sterling Jones, October 4, 1996). Thus, contraction scour for these discharges was computed by use of the Chang equation (Richardson and Davis, 1995, p. 145-146).

For comparison, contraction scour for the discharges resulting in orifice flow was also computed by use of the Laursen clear-water contraction scour equation (Richardson and Davis, 1995, p. 32, equation 20) and the Umbrell pressure-flow equation (Richardson and Davis, 1995, p. 144) and is presented in appendix F. Furthermore, for those discharges resulting in unsubmerged orifice flow, contraction scour was computed by substituting estimates for the depth of flow at the downstream bridge face in the contraction scour equations. Results with respect to these substitutions are provided in appendix F.

Abutment scour for the left abutment was computed by use of the Froehlich equation (Richardson and Davis, 1995, p. 48, equation 28). Variables for the Froehlich equation include the Froude number of the flow approaching the embankments, the length of the embankment blocking flow, and the depth of flow approaching the embankment less any roadway overtopping.

Scour at the right abutment was computed by use of the HIRE equation (Richardson and Davis, 1995, p. 49, equation 29) because the HIRE equation is recommended when the length to depth ratio of the embankment blocking flow exceeds 25 . The variables used by the HIRE abutment-scour equation are defined the same as those defined for the Froehlich abutment-scour equation. 


\section{Scour Results}

Contraction scour:

Main channel

Live-bed scour

Clear-water scour

Depth to armoring

Left overbank

Right overbank

Local scour:

Abutment scour

Left abutment

Right abutment

Pier scour

Pier 1

Pier 2

Pier 3
6.7

8.9-
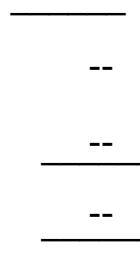

Incipient

500-year overtopping discharge discharge

(Scour depths in feet) 100-year
discharge

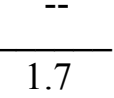

$\mathrm{N} / \mathrm{A}^{-}$

$-$

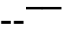

-

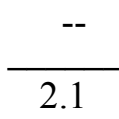

$\mathrm{N} / \mathrm{A}^{-}$
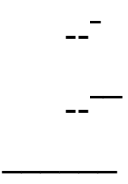

0.0

$\mathrm{N} / \mathrm{A}^{-}$

$--$

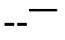

\section{Riprap Sizing}

Abutments:

Left abutment

100-year discharge

\section{9}

2.9

Right abutment

Piers:

Pier 1

Pier 2

7.3

8.7

$9.5-$

$7.8-$
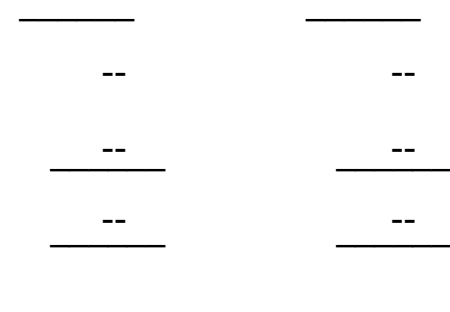

500-year overtopping discharge discharge (D $D_{50}$ in feet)

2.4

3.1

2.4
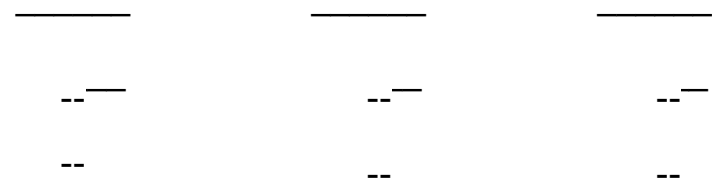


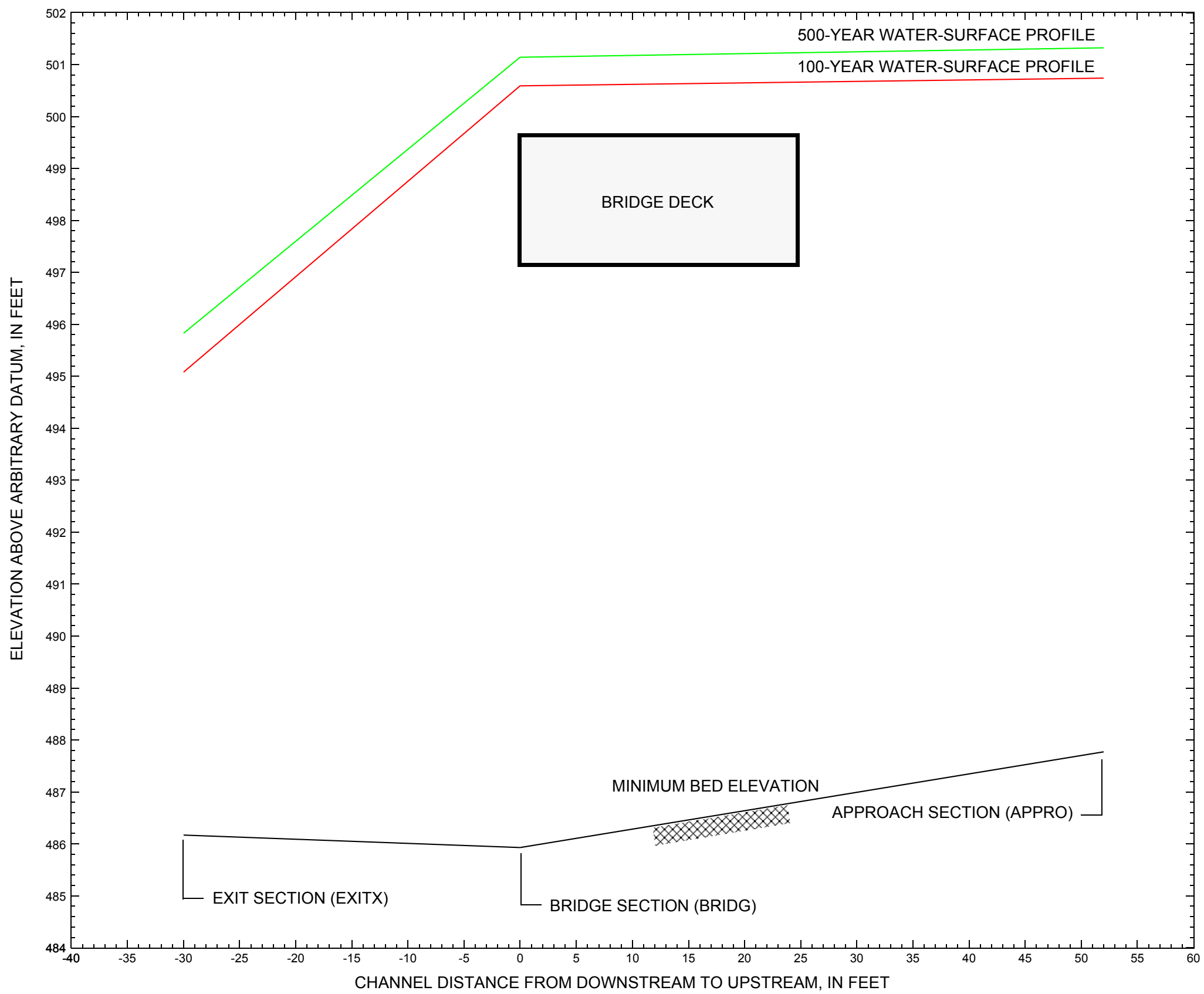

Figure 7. Water-surface profiles for the 100- and 500-year discharges at structure TOWNTH00290037 on Town Highway 29, crossing Mill Brook, Townshend, Vermont. 


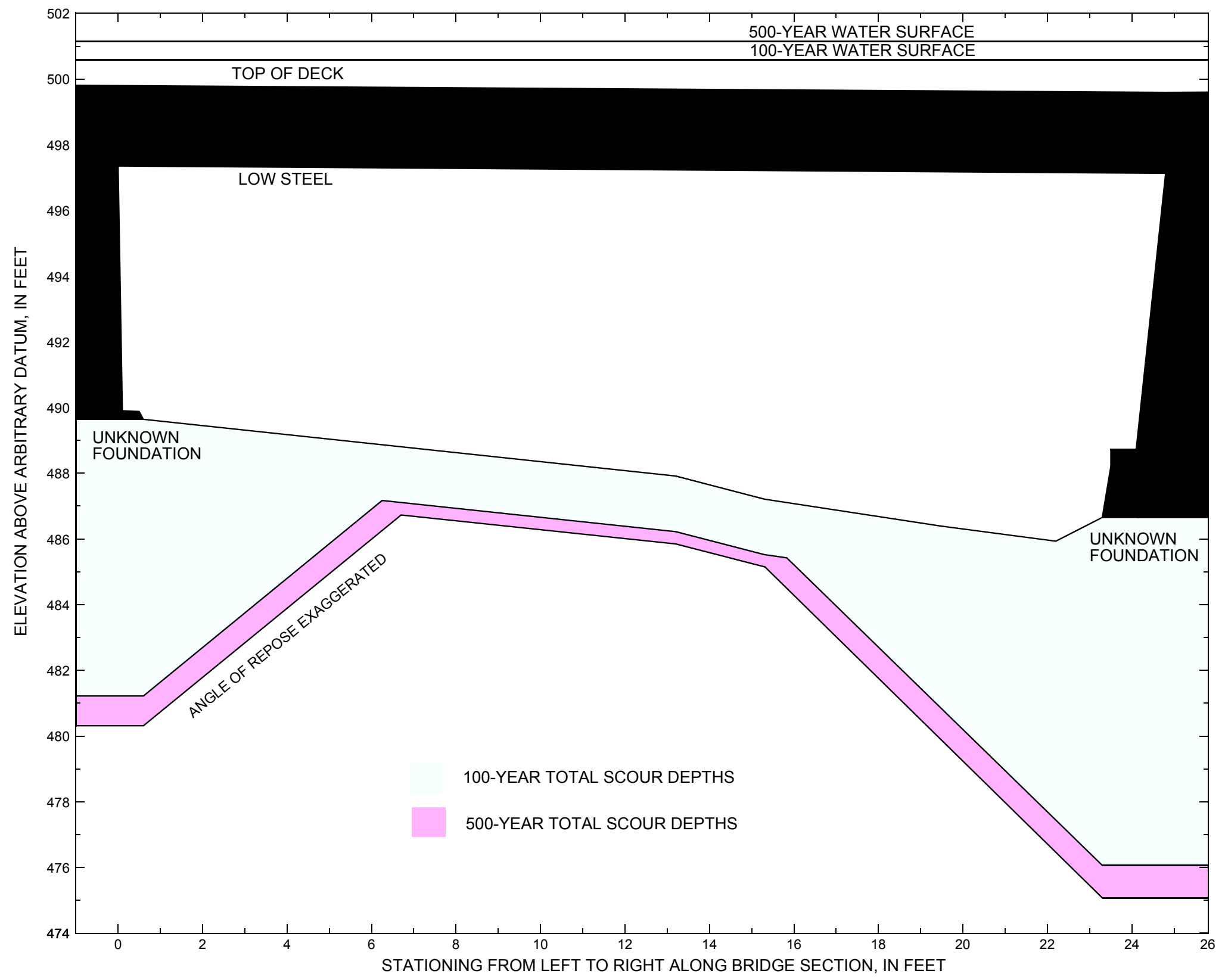

Figure 8. Scour elevations for the 100- and 500-year discharges at structure TOWNTH00290037 on Town Highway 29, crossing Mill Brook, Townshend, Vermont. 
Table 1. Remaining footing/pile depth at abutments for the 100-year discharge at structure TOWNTH00290037 on Town Highway 29, crossing Mill Brook, Townshend, Vermont.

[VTAOT, Vermont Agency of Transportation; --, no data]

\begin{tabular}{|c|c|c|c|c|c|c|c|c|c|c|c|}
\hline Description & Station $^{1}$ & $\begin{array}{l}\text { VTAOT } \\
\text { minimum } \\
\text { low-chord } \\
\text { elevation } \\
\text { (feet) }\end{array}$ & $\begin{array}{l}\text { Surveyed } \\
\text { minimum } \\
\text { low-chord } \\
\text { elevation } \\
\quad \text { (feet) }\end{array}$ & $\begin{array}{c}\text { Bottom of } \\
\text { footing/pile } \\
\text { elevation }{ }^{2} \\
\text { (feet) }\end{array}$ & $\begin{array}{c}\text { Channel } \\
\text { elevation at } \\
\text { abutment/ } \\
\text { pier }{ }^{2} \\
\text { (feet) }\end{array}$ & $\begin{array}{l}\text { Contraction } \\
\text { scour depth } \\
\text { (feet) }\end{array}$ & $\begin{array}{l}\text { Abutment } \\
\text { scour } \\
\text { depth } \\
\text { (feet) }\end{array}$ & $\begin{array}{l}\text { Pier } \\
\text { scour } \\
\text { depth } \\
\text { (feet) }\end{array}$ & $\begin{array}{l}\text { Depth of } \\
\text { total scour } \\
\text { (feet) }\end{array}$ & $\begin{array}{c}\text { Elevation of } \\
\text { scour }^{2} \\
\text { (feet) }\end{array}$ & $\begin{array}{c}\text { Remaining } \\
\text { footing/pile } \\
\text { depth } \\
\text { (feet) }\end{array}$ \\
\hline \multicolumn{12}{|c|}{100 -year discharge is 3,390 cubic-feet per second } \\
\hline Left abutment & 0.0 & -- & 497.4 & -- & 489.6 & 1.7 & 6.7 & -- & 8.4 & 481.2 & -- \\
\hline Right abutment & 24.8 & -- & 497.1 & -- & 486.7 & 1.7 & 8.9 & -- & 10.6 & 476.1 & -- \\
\hline
\end{tabular}

1.Measured along the face of the most constricting side of the bridge.

2.Arbitrary datum for this study.

Table 2. Remaining footing/pile depth at abutments for the 500-year discharge at structure TOWNTH00290037 on Town Highway 29, crossing Mill Brook, Townshend, Vermont.

[VTAOT, Vermont Agency of Transportation; --, no data]

\begin{tabular}{|c|c|c|c|c|c|c|c|c|c|c|c|}
\hline Description & Station $^{1}$ & $\begin{array}{l}\text { VTAOT } \\
\text { minimum } \\
\text { low-chord } \\
\text { elevation } \\
\text { (feet) }\end{array}$ & $\begin{array}{c}\text { Surveyed } \\
\text { minimum } \\
\text { low-chord } \\
\text { elevation } \\
\text { (feet) }\end{array}$ & $\begin{array}{c}\text { Bottom of } \\
\text { footing/pile } \\
\text { elevation } \\
\text { (feet) }\end{array}$ & $\begin{array}{c}\text { Channel } \\
\text { elevation at } \\
\text { abutment/ } \\
\text { pier }^{2} \\
\text { (feet) }\end{array}$ & $\begin{array}{l}\text { Contraction } \\
\text { scour depth } \\
\text { (feet) }\end{array}$ & $\begin{array}{c}\text { Abutment } \\
\text { scour } \\
\text { depth } \\
\text { (feet) }\end{array}$ & $\begin{array}{l}\text { Pier } \\
\text { scour } \\
\text { depth } \\
\text { (feet) }\end{array}$ & $\begin{array}{l}\text { Depth of } \\
\text { total scour } \\
\text { (feet) }\end{array}$ & $\begin{array}{c}\text { Elevation of } \\
\text { scour }^{2} \\
\text { (feet) }\end{array}$ & $\begin{array}{c}\text { Remaining } \\
\text { footing/pile } \\
\text { depth } \\
\text { (feet) }\end{array}$ \\
\hline \multicolumn{12}{|c|}{500 -year discharge is 4,600 cubic-feet per second } \\
\hline Left abutment & 0.0 & -- & 497.4 & -- & 489.6 & 2.1 & 7.3 & -- & 9.4 & 480.2 & -- \\
\hline Right abutment & 24.8 & -- & 497.1 & -- & 486.7 & 2.1 & 9.5 & -- & 11.6 & 475.1 & -- \\
\hline
\end{tabular}

1.Measured along the face of the most constricting side of the bridge.

2.Arbitrary datum for this study. 


\section{SELECTED REFERENCES}

Arcement, G.J., Jr., and Schneider, V.R., 1989, Guide for selecting Manning's roughness coefficients for natural channels and flood plains: U.S. Geological Survey Water-Supply Paper 2339, 38 p.

Barnes, H.H., Jr., 1967, Roughness characteristics of natural channels: U.S. Geological Survey Water-Supply Paper 1849,213 p.

Benson, M. A., 1962, Factors Influencing the Occurrence of Floods in a Humid Region of Diverse Terrain: U.S. Geological Survey WaterSupply Paper 1580-B, 64 p.

Brown, S.A. and Clyde, E.S., 1989, Design of riprap revetment: Federal Highway Administration Hydraulic Engineering Circular No. 11, Publication FHWA-IP-89-016, 156 p.

Federal Highway Administration, 1983, Runoff estimates for small watersheds and development of sound design: Federal Highway Administration Report FHWA-RD-77-158.

Federal Highway Administration, 1993, Stream Stability and Scour at Highway Bridges: Participant Workbook: Federal Highway Administration Report FHWA-HI-91-011.

Froehlich, D.C., 1989, Local scour at bridge abutments in Ports, M.A., ed., Hydraulic Engineering--Proceedings of the 1989 National Conference on Hydraulic Engineering: New York, American Society of Civil Engineers, p. 13-18.

Hayes, D.C.,1993, Site selection and collection of bridge-scour data in Delaware, Maryland, and Virginia: U.S. Geological Survey WaterResources Investigation Report 93-4017, 23 p.

Interagency Advisory Committee on Water Data, 1982, Guidelines for determining flood flow frequency: U.S. Geological Survey, Bulletin 17B of the Hydrology Subcommittee, 190 p.

Johnson, C.G. and Tasker, G.D.,1974, Progress report on flood magnitude and frequency of Vermont streams: U.S. Geological Survey OpenFile Report 74-130, 37 p.

Lagasse, P.F., Schall, J.D., Johnson, F., Richardson, E.V., Chang, F., 1995, Stream Stability at Highway Structures: Federal Highway Administration Hydraulic Engineering Circular No. 20, Publication FHWA-IP-90-014, 144 p.

Laursen, E.M., 1960, Scour at bridge crossings: Journal of the Hydraulics Division, American Society of Civil Engineers, v. 86, no. HY2, p. 39-53.

Potter, W. D., 1957a, Peak rates of runoff in the Adirondack, White Mountains, and Maine woods area, Bureau of Public Roads

Potter, W. D., 1957b, Peak rates of runoff in the New England Hill and Lowland area, Bureau of Public Roads

Richardson, E.V. and Davis, S.R., 1995, Evaluating scour at bridges: Federal Highway Administration Hydraulic Engineering Circular No. 18, Publication FHWA-IP-90-017, 204 p.

Richardson, E.V., Simons, D.B., and Julien, P.Y., 1990, Highways in the river environment: Federal Highway Administration Publication FHWA-HI-90-016.

Ritter, D.F., 1984, Process Geomorphology: W.C. Brown Co., Debuque, Iowa, 603 p.

Shearman, J.O., 1990, User's manual for WSPRO--a computer model for water surface profile computations: Federal Highway Administration Publication FHWA-IP-89-027, 187 p.

Shearman, J.O., Kirby, W.H., Schneider, V.R., and Flippo, H.N., 1986, Bridge waterways analysis model; research report: Federal Highway Administration Publication FHWA-RD-86-108, 112 p.

Talbot, A.N., 1887, The determination of water-way for bridges and culverts.

U.S. Geological Survey, 1984, Townshend, Vermont 7.5 Minute Series quadrangle map: U.S. Geological Survey Topographic Maps, Scale $1: 25,000$. 


\section{APPENDIX A: \\ WSPRO INPUT FILE}




\section{WSPRO INPUT FILE}

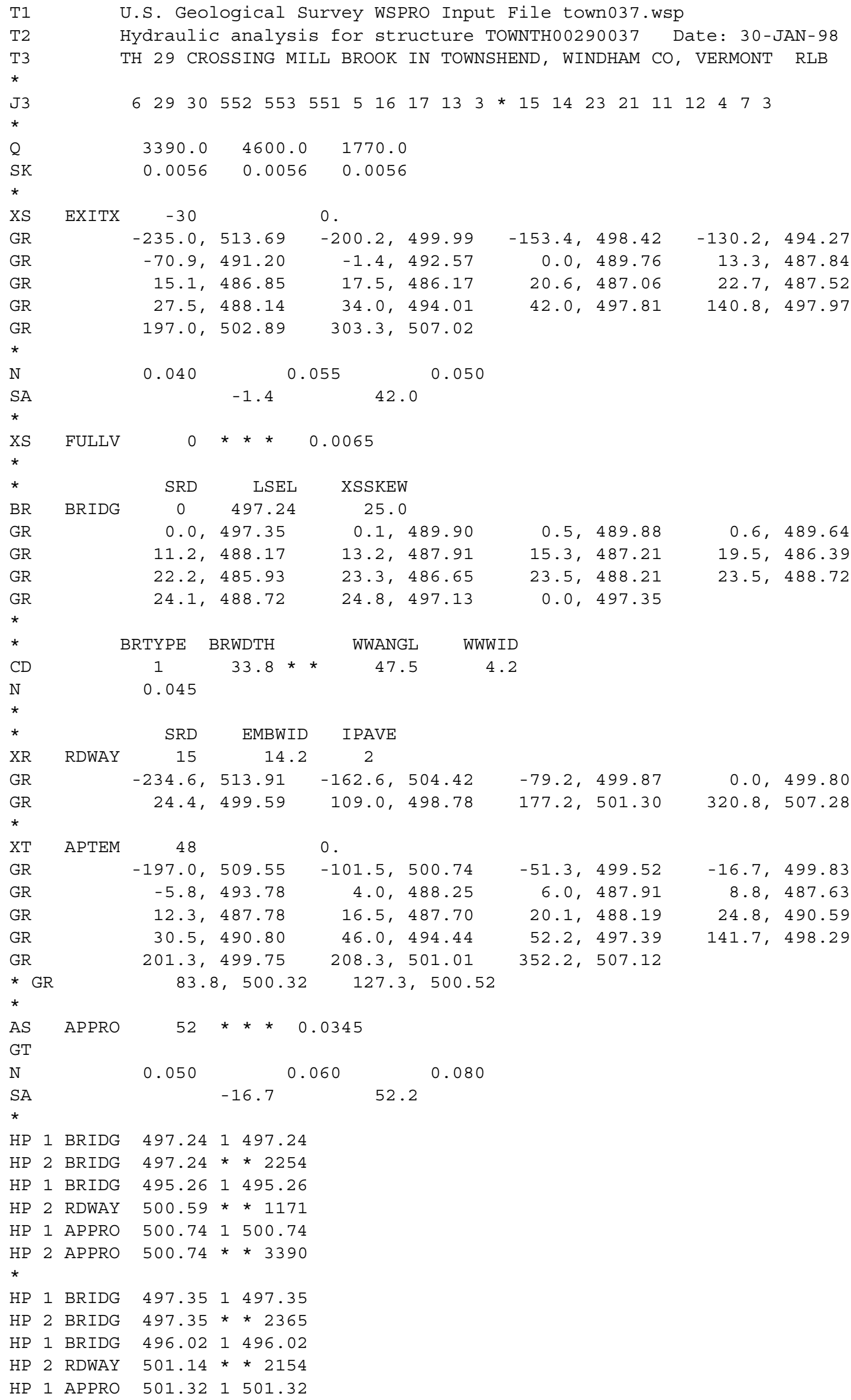




\section{APPENDIX B: \\ WSPRO OUTPUT FILE}




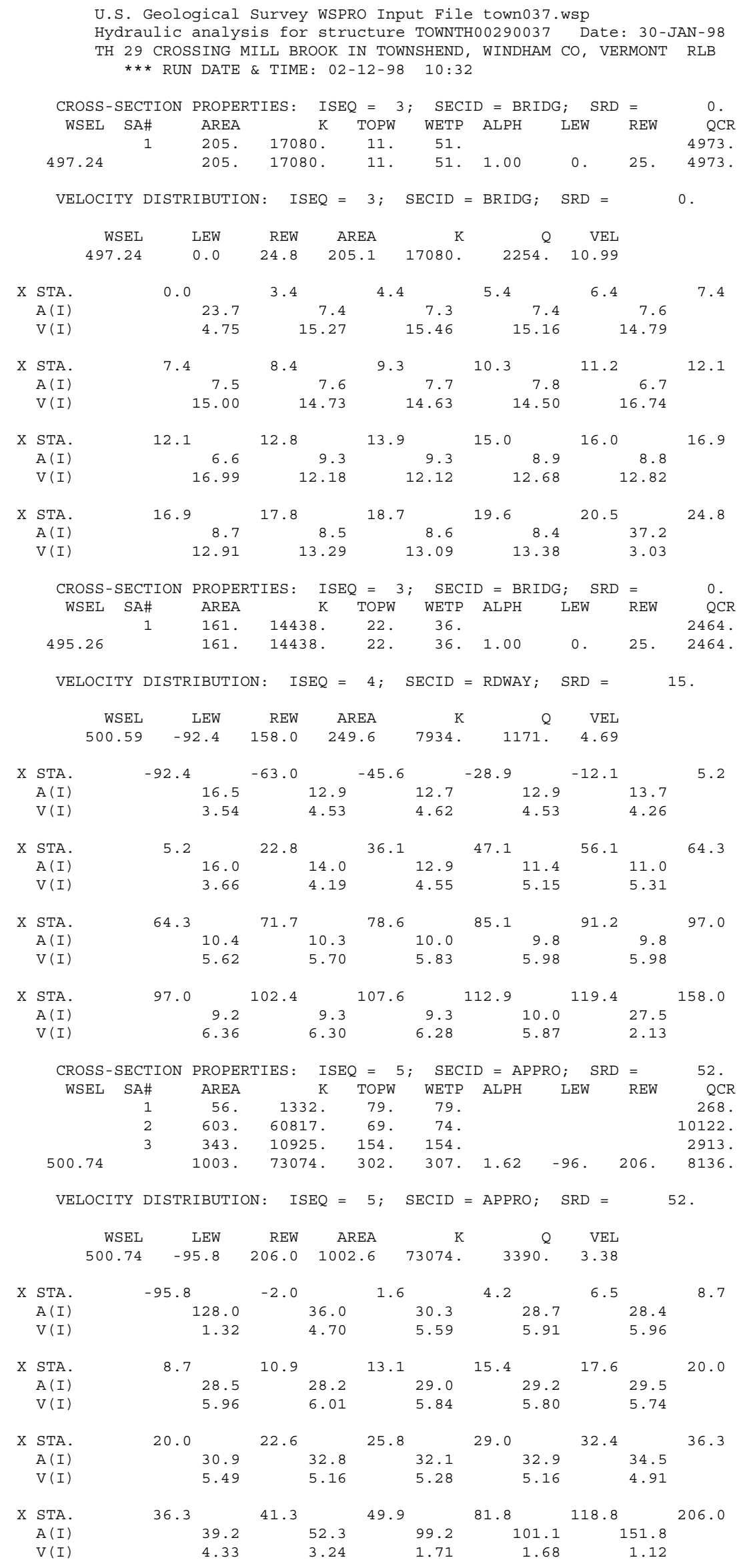




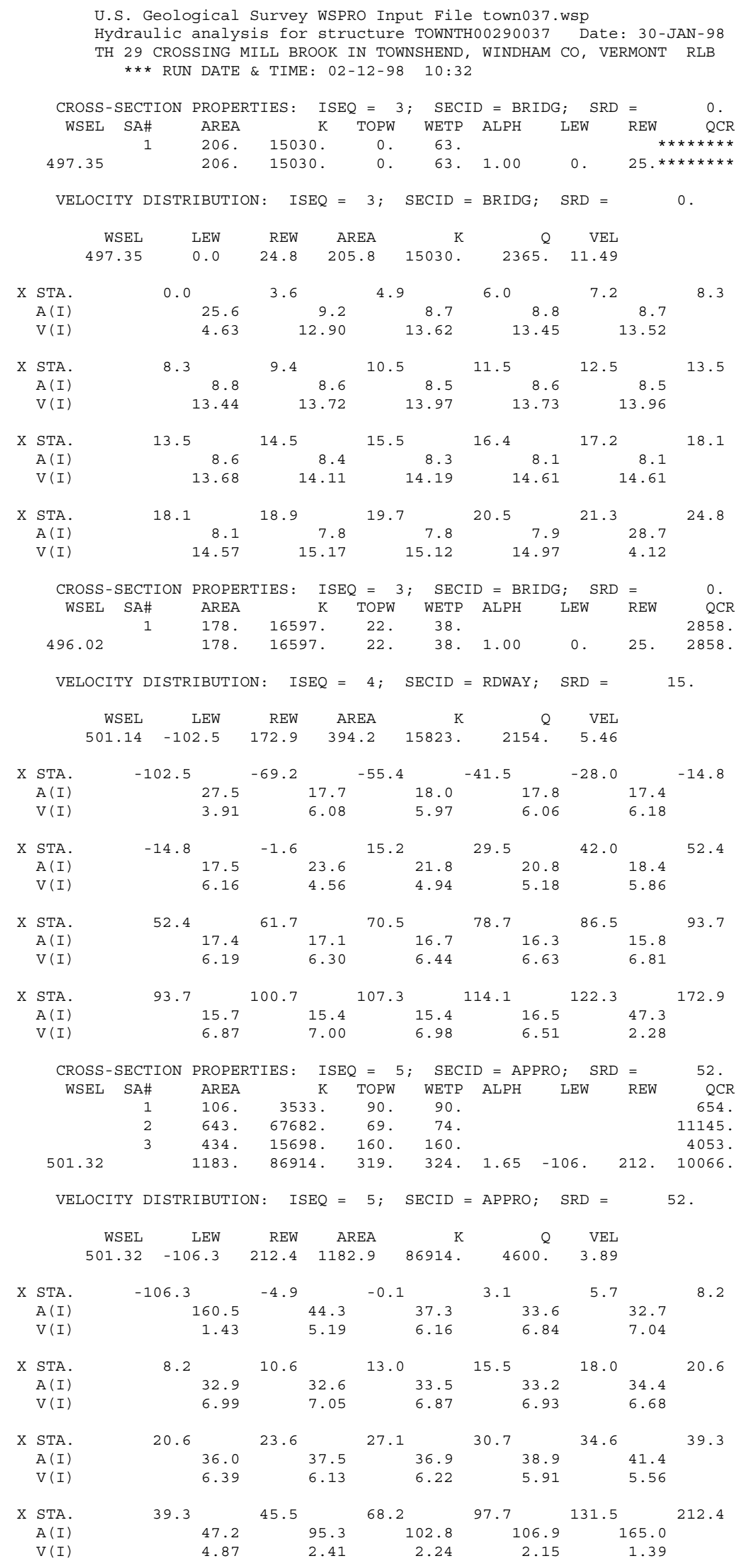


WSPRO OUTPUT FILE (continued)

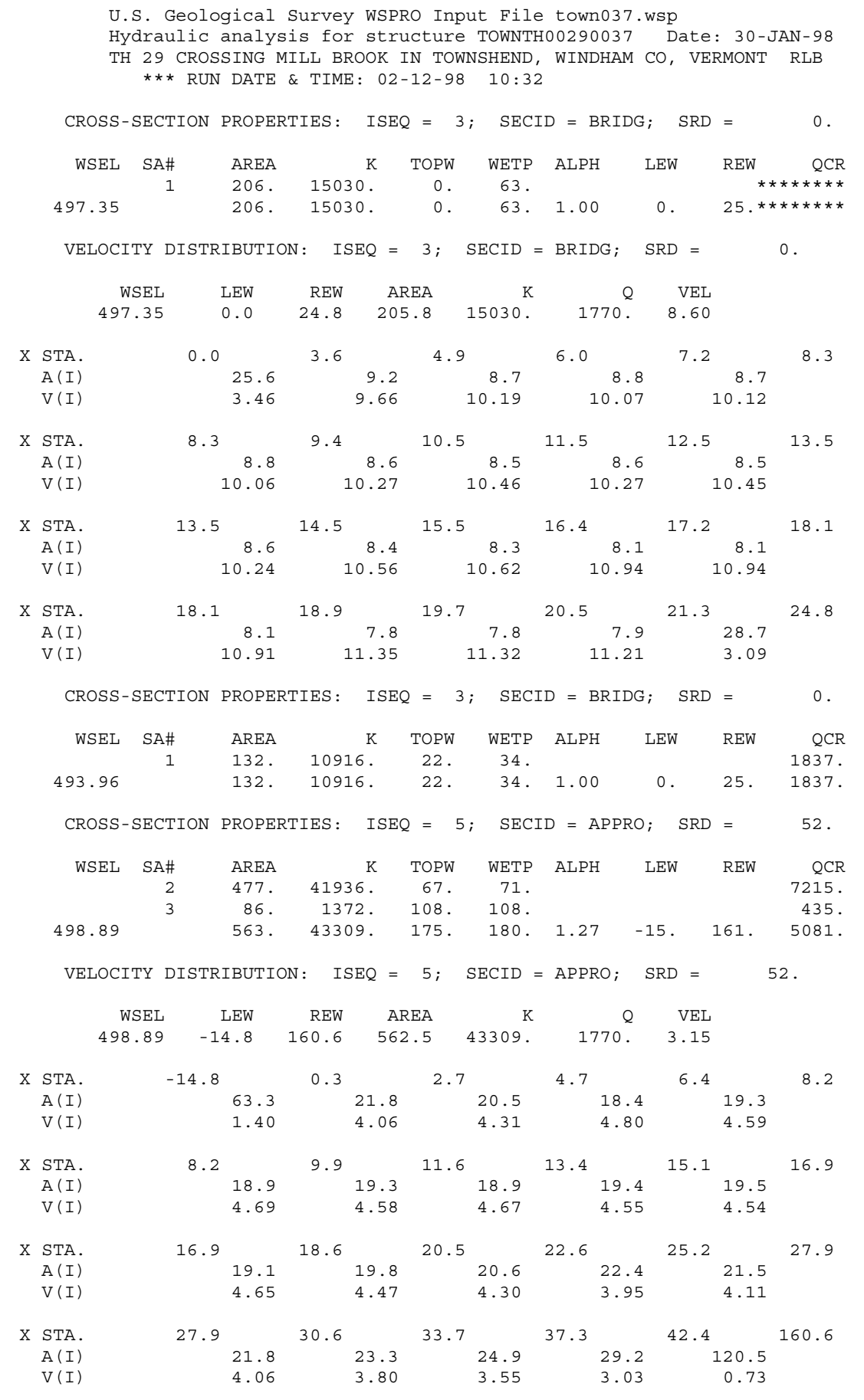


WSPRO OUTPUT FILE (continued)

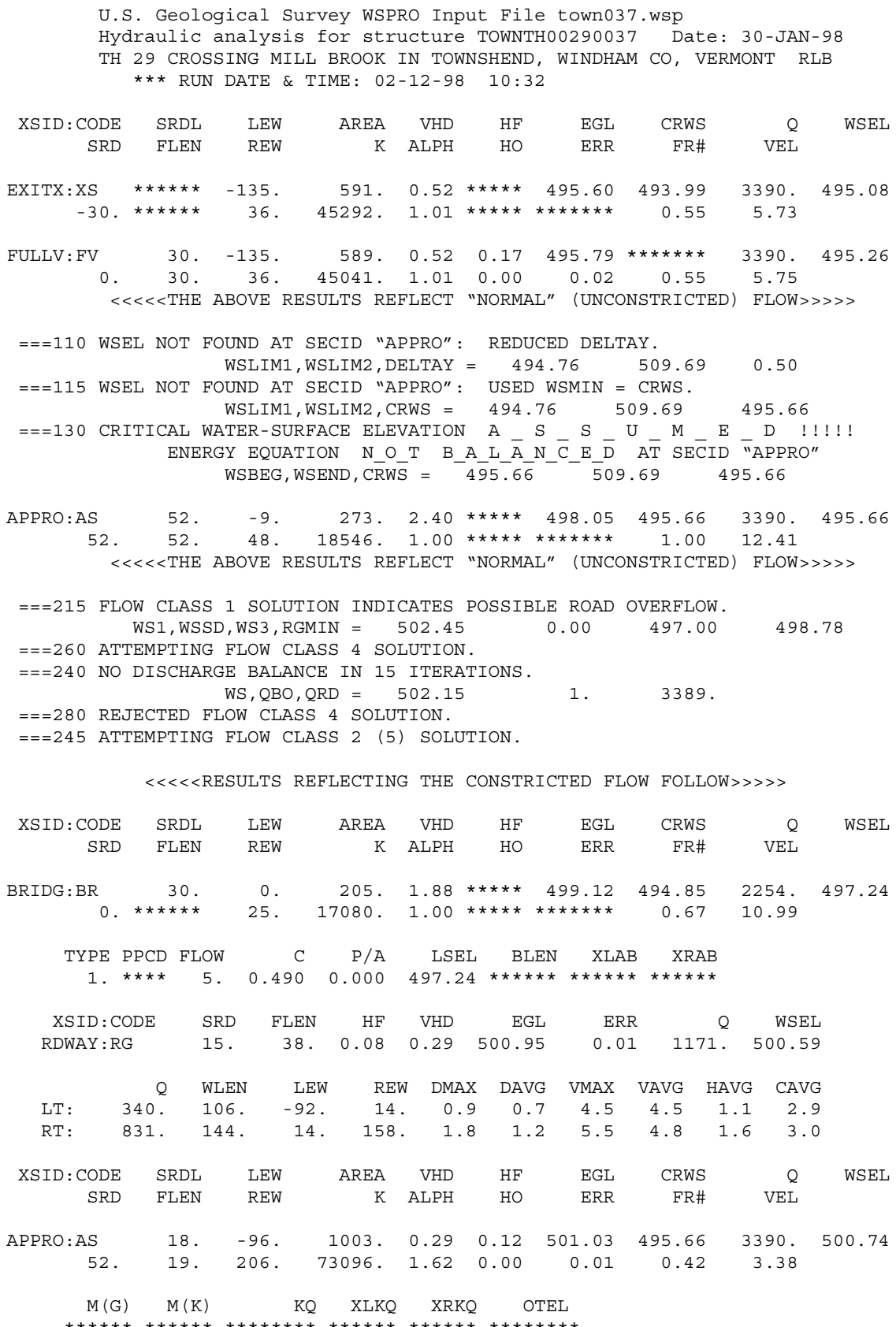


WSPRO OUTPUT FILE (continued)

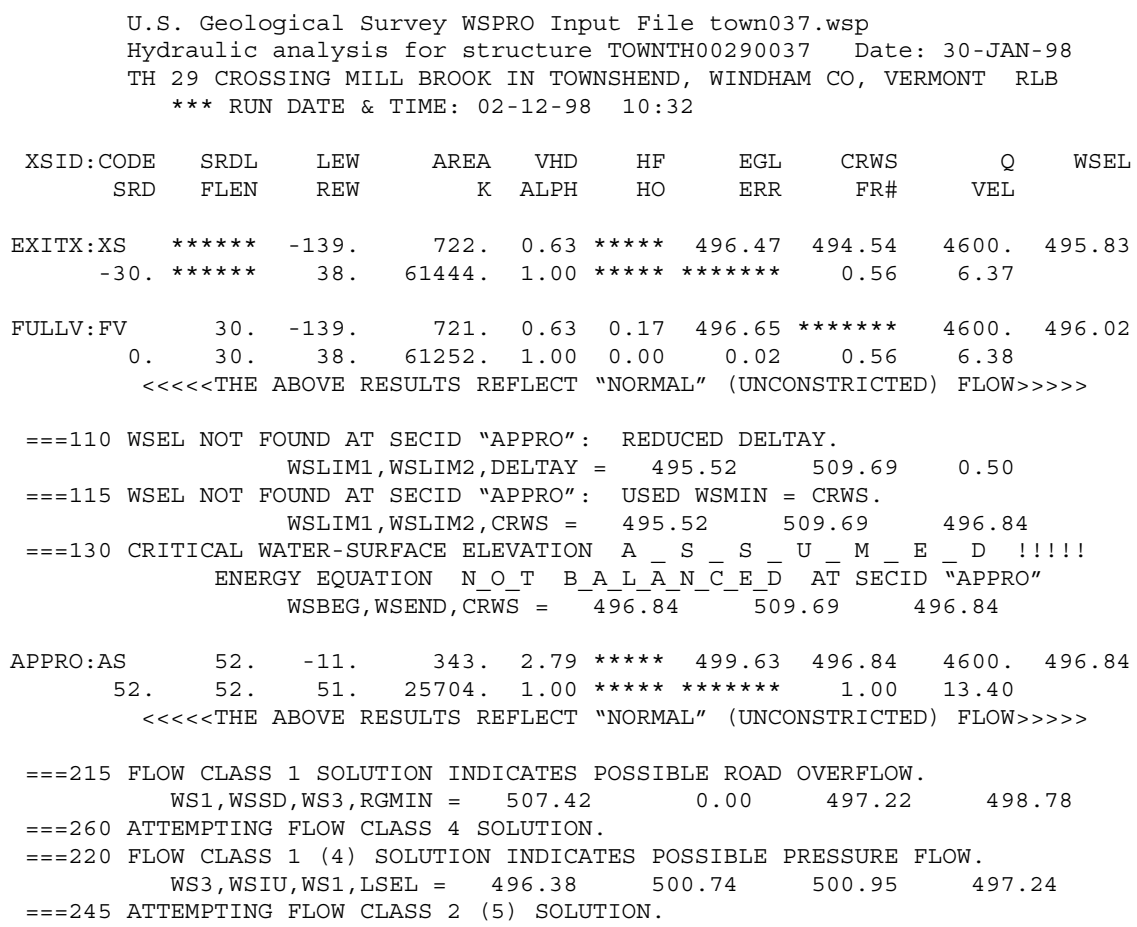

FIRST USER DEFINED TABLE.

\begin{tabular}{|c|c|c|c|c|c|c|c|c|}
\hline XSID : CODE & SRD & LEW & REW & Q & K & AREA & VEL & WSEL \\
\hline EXITX:XS & -30 & -139 & 38. & 4600. & 61444 & 722 . & 6.37 & 495.83 \\
\hline FULLV : FV & 0 . & -139. & 38. & 4600 . & 61252 & 721. & 6.38 & 496.02 \\
\hline BRIDG : BR & 0 . & 0 . & 25. & 2365 . & 15030 . & 206 . & 11.49 & 497.35 \\
\hline RDWAY : RG & 15. * & 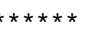 & 730. & 2154 . & 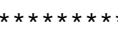 & 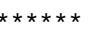 & 2.00 & 501.14 \\
\hline APPRO: AS & 52. & -106 & 212 . & 4600 . & 87026 . & 1184 & 3.88 & 501.32 \\
\hline XSID : CODE & XLKQ & XRKQ & \multirow{2}{*}{\multicolumn{4}{|c|}{ KQ }} & & \\
\hline APPRO:AS & & & & & & & & \\
\hline
\end{tabular}

SECOND USER DEFINED TABLE.

$\begin{array}{lcrrrrrrrr}\text { XSID : CODE } & \text { CRWS } & \text { FR\# } & \text { YMIN } & \text { YMAX } & \text { HF } & \text { HO } & \text { VHD } & \text { EGL } & \text { WSEL } \\ \text { EXITX:XS } & 494.54 & 0.56 & 486.17 & 513.69 * * * * * * * * * * & 0.63 & 496.47 & 495.83 \\ \text { FULLV : FV } & * * * * * * * * & 0.56 & 486.37 & 513.89 & 0.17 & 0.00 & 0.63 & 496.65 & 496.02 \\ \text { BRIDG : BR } & 495.07 & 0.70 & 485.93 & 497.35 * * * * * * * * * * & 2.05 & 499.40 & 497.35 \\ \text { RDWAY : RG } & * * * * * * * * * * * * * * * & 498.78 & 513.91 & 0.11 * * * * * * & 0.39 & 501.61 & 501.14 \\ \text { APPRO : AS } & 496.84 & 0.46 & 487.77 & 509.69 & 0.19 & 0.94 & 0.39 & 501.71 & 501.32\end{array}$


WSPRO OUTPUT FILE (continued)

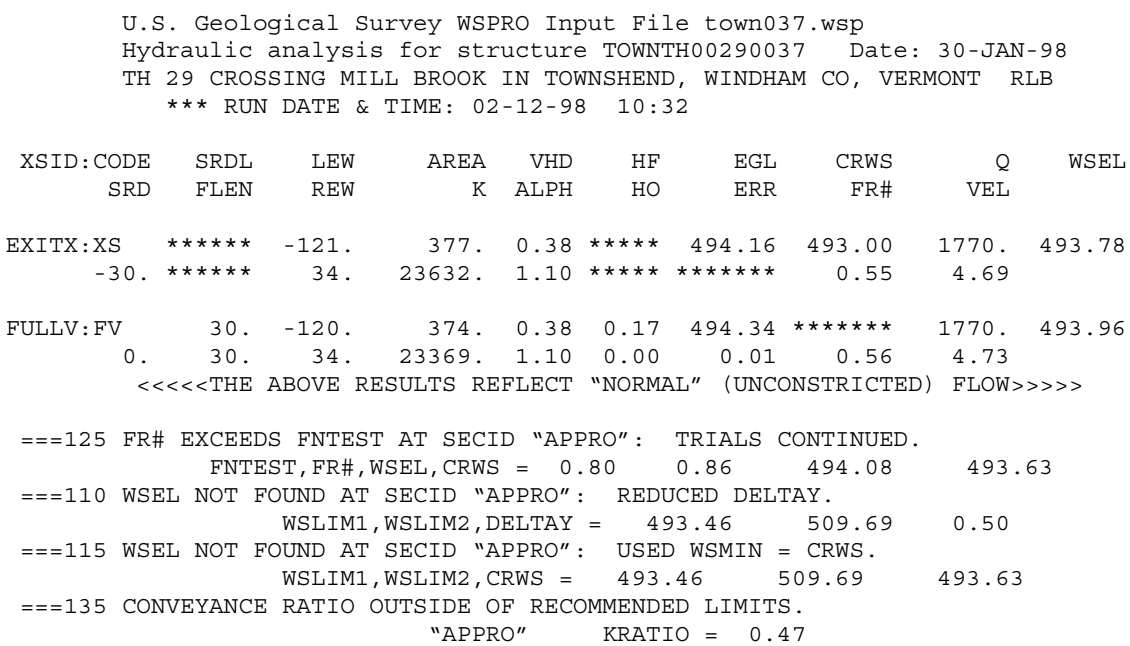

SECOND USER DEFINED TABLE.

\begin{tabular}{|c|c|c|c|c|c|c|c|c|c|}
\hline XSID: CODE & CRWS & FR\# & YMIN & YMAX & $\mathrm{HF}$ & $\mathrm{HO}$ & VHD & EGL & WSE \\
\hline EXITX:XS & 493.00 & 0.55 & 486.17 & $513.69 *$ & $* * \star * * *$ & $\star \star \star \star \star *$ & 0.38 & 494.16 & 493 \\
\hline FULLV : FV & $\star \star \star \star * \star * \star * *$ & 0.56 & 486.37 & 513.89 & 0.17 & 0.00 & 0.38 & 494.34 & 4 \\
\hline BRIDG : BR & 493.81 & 0.53 & 485.93 & $497.35 *$ & $* * * * * * *$ & $* \star \star \star \star *$ & 1.15 & 498.50 & 497.3 \\
\hline RDWAY : RG & $\star \star \star \star \star \star \star \star \star * *$ & $* \star \star * *$ & 498.78 & 513.91 * & $* * * * * * *$ & $* \star \star \star \star *$ & 0.19 & $499.02 * *$ & \\
\hline APPRO: AS & 493.63 & 0.35 & 487.77 & 509.69 & 0.09 & 0.95 & 0.19 & 499.09 & 498 \\
\hline
\end{tabular}




\section{APPENDIX C:}

\section{BED-MATERIAL PARTICLE-SIZE DISTRIBUTION}




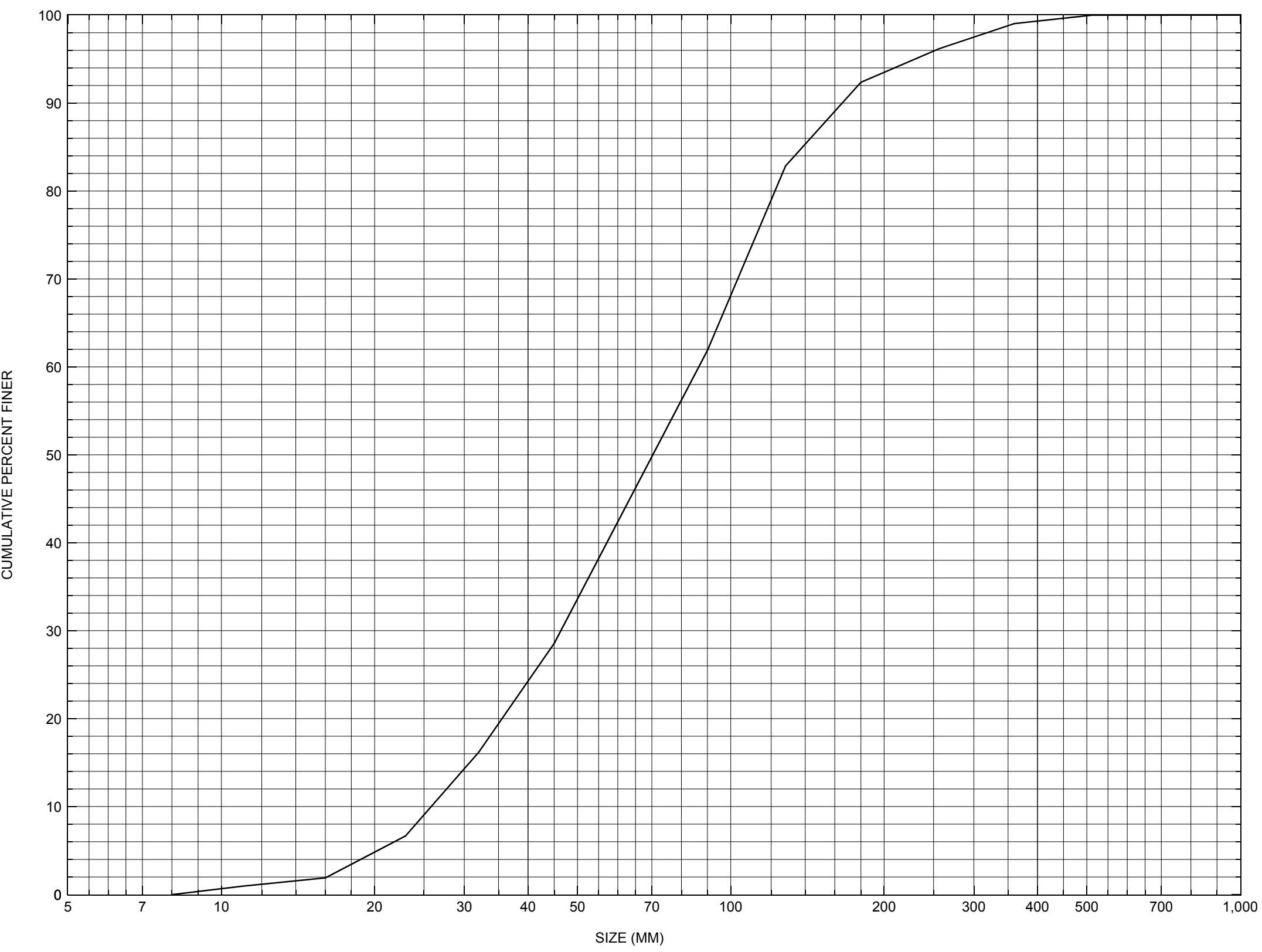

Appendix C. Bed material particle-size distribution for a pebble count in the channel approach of structure TOWNTH00290037, in Townshend, Vermont. 


\section{APPENDIX D: \\ HISTORICAL DATA FORM}




\section{Structure Number TOWNTH00290037}

\section{General Location Descriptive}

Data collected by (First Initial, Full last name) $\mathbf{M}$. IVANOFF

Date $(M M / D D / Y Y) \_\mathbf{0 4} / \underline{07} / \underline{95}$

Highway District Number (I - 2; nn) $\mathbf{0 2}$

Town (FIPS place code; I - 4; nnnnn) $\mathbf{7 3 3 0 0}$

Waterway (I - 6) MILL BROOK

Route Number $\underline{\text { TH029 }}$

Topographic Map Townshend

Latitude (I - 16; nnnn.n) $\mathbf{4 3 0 2 8}$
County (FIPS county code; I - 3; nnn)

Mile marker (I - 11; nnn.nnn) $\mathbf{0 0 0 0 0 0}$

Road Name (I - 7): -

Vicinity (I - 9) 0.1 MI JCT TH 29 \& VT 35

Hydrologic Unit Code: $\mathbf{0 1 0 8 0 1 0 7}$

Longitude (i - 17; nnnnn.n) $\mathbf{7 2 3 9 8}$

\section{Select Federal Inventory Codes}

FHWA Structure Number (I - 8) $\mathbf{1 0 1 3 1 7 0 0 3 7 1 3 1 7}$

Maintenance responsibility $(I-21 ; n n) \quad \mathbf{0 3}$

Year built (I - 27; YYYY) 1939

Average daily traffic, ADT (I - 29; nnnnnn) 000050

Year of ADT (I - 30; YY) $\mathbf{9 0}$

Opening skew to Roadway $(I-34 ; n n) \quad \mathbf{2 0}$

Operational status $(I-41 ; X) \quad \mathbf{P}$

Structure type (I - 43; nnn) $\mathbf{3 0 3}$

Approach span structure type (I - 44; nnn) $\mathbf{0 0 0}$

Number of spans (I - 45; nnn) $\mathbf{0 0 1}$

Number of approach spans (I - 46; nnnn) $\mathbf{0 0 0 0}$

Comments:

The structural inspection report of $07 / 11 / 94$ indicates the structure is a single span, steel beam type bridge with a concrete deck and an asphalt roadway surface. Both abutments are laid up stone with new reinforced concrete facings. The laid up stone walls also have older concrete bearing caps. The right abutment facing is roughly 18 inches below the bottom flanges of the main beams. At the left abutment the newer concrete facing covers the full wall height. Newer concrete footings are in view, but there is no apparent undermining. The waterway makes a moderate to sharp turn through the structure, and much of the flow is along the right abutment. The streambed consists of stone and gravel with some (Continued, page 33) 


\section{Bridge Hydrologic Data}

Is there hydrologic data available? $\underline{\mathbf{N}}$ if No, type ctrl-n $h \quad$ VTAOT Drainage area $\left(m i^{2}\right)$ : -

Terrain character:

Stream character \& type: -

Streambed material:

Discharge Data (cfs):

$$
\begin{aligned}
& Q_{2.33}- \\
& Q_{50}-
\end{aligned}
$$

Record flood date $(M M / D D / Y Y)$ :

Estimated Discharge (cfs): Ice conditions (Heavy, Moderate, Light) : -

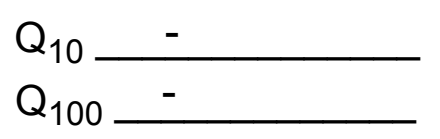

$$
\begin{aligned}
& Q_{25}- \\
& Q_{500}-
\end{aligned}
$$

Water surface elevation $(f t):-$

The stage increases to maximum highwater elevation (Rapidly, Not rapidly):

The stream response is (Flashy, Not flashy):

Describe any significant site conditions upstream or downstream that may influence the stream's stage: -

Watershed storage area (in percent): _ _ \%

The watershed storage area is: - (1-mainly at the headwaters; 2- uniformly distributed; 3-immediatly upstream oi the site)

Water Surface Elevation Estimates for Existing Structure:

\begin{tabular}{|l|l|l|l|l|l|}
\hline Peak discharge frequency & $Q_{2.33}$ & $Q_{10}$ & $Q_{25}$ & $Q_{50}$ & $Q_{100}$ \\
Water surface elevation (ft)) & - & - & - & - & - \\
Velocity (ft/sec) & - & - & - & - & - \\
\hline
\end{tabular}

Long term stream bed changes: -

Is the roadway overtopped below the $\mathrm{Q}_{100}$ ? (Yes, No, Unknown): $\mathbf{U}$ Frequency: Relief Elevation (ft): Discharge over roadway at $Q_{100}\left(f^{3} / \mathrm{sec}\right)$ :

Are there other structures nearby? (Yes, No, Unknown): $\underline{\mathbf{U}}$ Upstream distance (miles): Town: If No or Unknown, type ctrl-n os Highway No. : Structure No. : Year Built:

Clear span (ft): Clear Height $(f t)$ : Full Waterway $\left(f^{2}\right)$ : 
Downstream distance (miles): Town: Year Built:

Highway No. : Structure No. : Structure Type:

Clear span (ft): Clear Height $(f t)$ : Full Waterway $\left(f^{2}\right)$ :

Comments:

moderately sized boulders. The bank protection consists of stone and some boulders.

\section{USGS Watershed Data}

Watershed Hydrographic Data

Drainage area $(D A) \underline{\mathbf{1 3 . 8 6}} \mathrm{mi}^{2}$ Lake/pond/swamp area 0.04 $\mathrm{mi}^{2}$

Watershed storage (ST) 0.3

Bridge site elevation 532 $\mathrm{ft}$ $\%$

Main channel length 5.49 $\mathrm{mi}$ $10 \%$ channel length elevation $\mathbf{6 1 0}$ $\mathrm{ft} \quad 85 \%$ channel length elevation $\mathrm{ft}$

Main channel slope $(S) \quad \mathbf{2 1 0 . 3 6} \mathrm{ft} / \mathrm{mi}$

Watershed Precipitation Data

Average site precipitation in Average headwater precipitation in

Maximum 2yr-24hr precipitation event $(124,2)$ in

Average seasonal snowfall (Sn) $\mathrm{ft}$ 


\section{Bridge Plan Data}

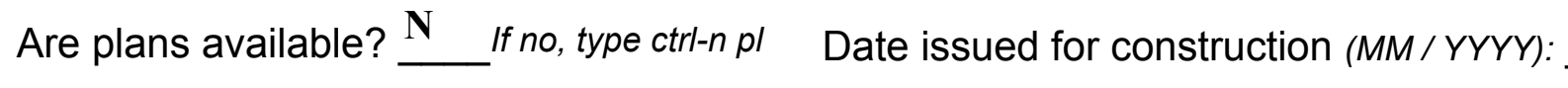

Project Number

Minimum channel bed elevation:

Low superstructure elevation: USLAB DSLAB USRAB DSRAB Benchmark location description:

NO BENCHMARK INFORMATION

Reference Point (MSL, Arbitrary, Other): Datum (NAD27, NAD83, Other):

Foundation Type: 4

If 1 : Footing Thickness

If 2: Pile Type:

If 3: Footing bottom elevation:

Is boring information available? $\mathbf{N}$

Foundation Material Type: $\mathbf{3}$

(1-Spreadfooting; 2-Pile; 3- Gravity; 4-Unknown)

Footing bottom elevation: -

Briefly describe material at foundation bottom elevation or around piles:

NO FOUNDATION MATERIAL INFORMATION 


\section{Cross-sectional Data}

Is cross-sectional data available? $\underline{\mathbf{N}}$ If no, type ctrl-n xs

Source (FEMA, VTAOT, Other)? -

Comments: NO CROSS SECTION INFORMATION

\begin{tabular}{|l|l|l|l|l|l|l|l|l|l|l|l|}
\hline Station & - & - & - & - & - & - & - & - & - & - & - \\
\hline Feature & - & - & - & - & - & - & - & - & - & - & - \\
\hline $\begin{array}{l}\text { Low chord } \\
\text { elevation }\end{array}$ & - & - & - & - & - & - & - & - & - & - & - \\
\hline $\begin{array}{l}\text { Bed } \\
\text { elevation }\end{array}$ & - & - & - & - & - & - & - & - & - & - & - \\
\hline $\begin{array}{l}\text { Low chord } \\
\text { to bed }\end{array}$ & - & - & - & - & - & - & - & - & - & - & - \\
\hline Station & - & - & - & - & - & - & - & - & - & - & - \\
\hline Feature & - & - & - & - & - & - & - & - & - & - & - \\
\hline $\begin{array}{l}\text { Low chord } \\
\text { elevation }\end{array}$ & - & - & - & - & - & - & - & - & - & - & - \\
\hline $\begin{array}{l}\text { Bed } \\
\text { elevation }\end{array}$ & - & - & - & - & - & - & - & - & - & - & - \\
\hline $\begin{array}{l}\text { Low chord } \\
\text { to bed }\end{array}$ & - & - & - & - & - & - & - & - & - & - & - \\
\hline
\end{tabular}

Source (FEMA, VTAOT, Other)?

Comments: NO CROSS SECTION INFORMATION

\begin{tabular}{|l|l|l|l|l|l|l|l|l|l|l|l|}
\hline Station & - & - & - & - & - & - & - & - & - & - & - \\
\hline Feature & - & - & - & - & - & - & - & - & - & - & - \\
\hline $\begin{array}{l}\text { Low chord } \\
\text { elevation }\end{array}$ & - & - & - & - & - & - & - & - & - & - & - \\
\hline $\begin{array}{l}\text { Bed } \\
\text { elevation }\end{array}$ & - & - & - & - & - & - & - & - & - & - & - \\
\hline $\begin{array}{l}\text { Low chord } \\
\text { to bed }\end{array}$ & - & - & - & - & - & - & - & - & - & - & - \\
\hline Station & - & - & - & - & - & - & - & - & - & - & - \\
\hline Feature & - & - & - & - & - & - & - & - & - & - & - \\
\hline $\begin{array}{l}\text { Low chord } \\
\text { elevation }\end{array}$ & - & - & - & - & - & - & - & - & - & - & - \\
\hline $\begin{array}{l}\text { Bed } \\
\text { elevation }\end{array}$ & - & - & - & - & - & - & - & - & - & - & - \\
\hline $\begin{array}{l}\text { Low chord } \\
\text { to bed }\end{array}$ & - & - & - & - & - & - & - & - & - & - & - \\
\hline
\end{tabular}




\section{APPENDIX E: \\ LEVEL I DATA FORM}




\section{A. General Location Descriptive}

1. Data collected by (First Initial, Full last name) L. MEDALIE

2. Highway District Number $\mathbf{0 2}$

County WINDHAM (025)

Waterway (I - 6) MILL BROOK

Route Number TH29

3. Descriptive comments:

Located 0.1 miles from the junction of TH 29 and VT 35. A conversation with a nearby resident revealed that several beaver dams US broke this past year and some clear-cutting has been done in the area. This has increased the water levels causing the DS left overbank to flood, which was not a common occurrence previously. Also, some of the stream water from US is diverted into a fire pond on the US right bank.

\section{B. Bridge Deck Observations}

\section{Surface cover... $\quad$ LBUS $6 \quad$ RBUS $6 \quad$ LBDS $4 \quad$ RBDS 5 Overall 6}

(2b us,ds,lb,rb: 1- Urban; 2- Suburban; 3- Row crops; 4- Pasture; 5- Shrub- and brushland; 6- Forest; 7- Wetland)
5. Ambient water surface... US 1
UB 1
DS 1
(1- pool; 2- riffle)

6. Bridge structure type 1 (1- single span; 2-multiple span; 3- single arch; 4- multiple arch; 5-cylindrical culvert; 6- box culvert; or 7-other)

7. Bridge length $\mathbf{3 3}$ (feet)

\section{Road approach to bridge:}
8. LB 0 RB 2
( 0 even, 1- lower, 2- higher)
9. LB 2 RB 1
(1- Paved, 2- Not paved)

10. Embankment slope (run / rise in feet / foot):

US left

US right

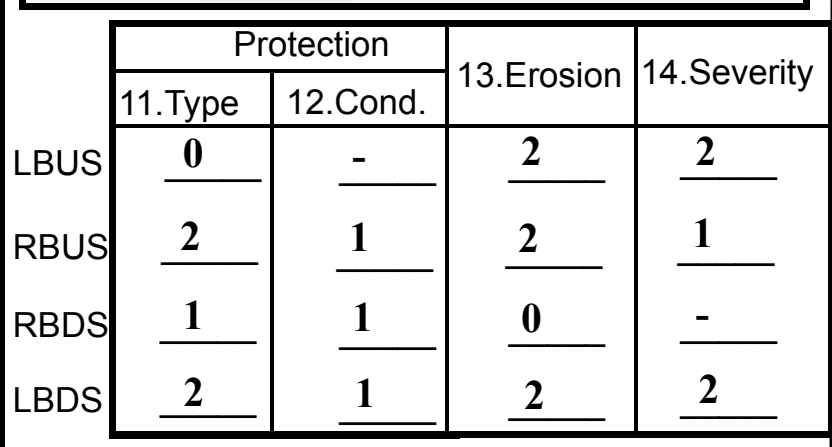

Bank protection types: 0- none; 1- $<12$ inches;

2- < 36 inches; 3- < 48 inches;

4- < 60 inches; 5- wall / artificial levee

Bank protection conditions: 1- good; 2- slumped;

3- eroded; 4- failed

Erosion: 0 - none; 1- channel erosion; 2-

road wash; 3- both; 4- other

Erosion Severity: 0 - none; 1- slight; 2- moderate; 3- severe
Span length $\mathbf{3 0}$ (feet)
Bridge width 14.2 (feet)

\section{Channel approach to bridge (BF):}

15. Angle of approach: $\mathbf{6 5}$

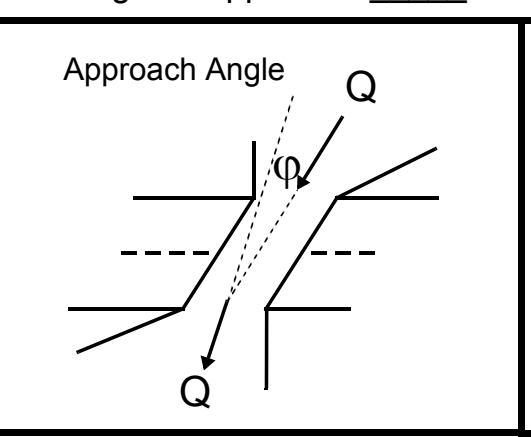

17. Channel impact zone 1:

Where? RB (LB, RB)

Range? 14 feet US

Channel impact zone 2:

Where? LB $(L B, R B)$

Range? 120 feet $\underline{\mathbf{U S}}$ (US, UB, DS) to $\underline{\mathbf{1 7 0}}$ feet $\underline{\mathbf{U S}}$

Impact Severity: 0- none to very slight; 1- Slight; 2- Moderate; 3- Severe
16. Bridge skew: 45

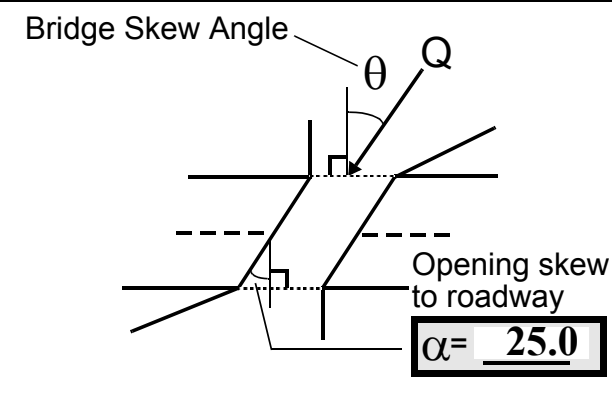

Exist? $\underline{Y}(Y$ or $N)$

Severity 2

(US, UB, DS) to $\underline{\mathbf{1 0}}$ feet $\underline{\mathbf{D S}}$

Exist? $\mathbf{Y}(Y$ or $N)$

Severity 1 
18. Bridge Type: 1a

1a- Vertical abutments with wingwalls

1 b- Vertical abutments without wingwalls

2- Vertical abutments and wingwalls, sloping embankment Wingwalls parallel to abut. face

3- Spill through abutments

4- Sloping embankment, vertical wingwalls and abutments

Wingwall angle less than $90^{\circ}$.

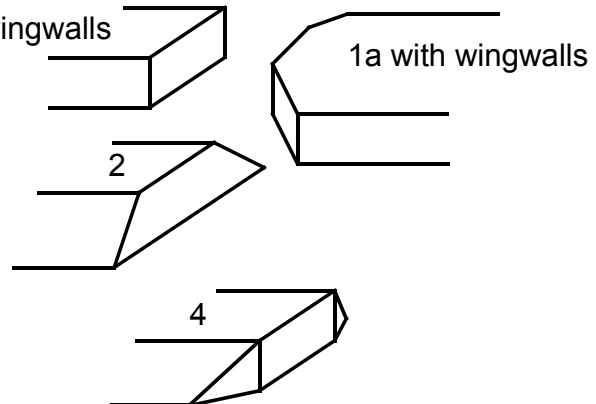

19. Bridge Deck Comments (surface cover variations, measured bridge and span lengths, bridge type variations, approach overflow width, etc.)

4. The left bank DS is lined with trees, but the overbank is a mix of grass and a hard packed dirt area with cars, logs and sheds. The right bank DS also has some trees, but is mostly a dirt parking area. The right bank US has an area of trees near the bridge then there is a house and lawn beyond.

7. Values are from the VTAOT files. Measured bridge width is $14.1 \mathrm{ft}$, bridge length is $30.9 \mathrm{ft}$, and the span length is $24.1 \mathrm{ft}$.

11. On the right DS road embankment, there are a few stones mostly buried in the grass. The US right road embankment has boulders piled on top of the wingwall. On the left bank US the embankment is steep from the road to the channel and there is some vegetation, but not extensive enough to prevent erosion. The left road embankment protection DS is sparce.

\section{Upstream Channel Assessment}

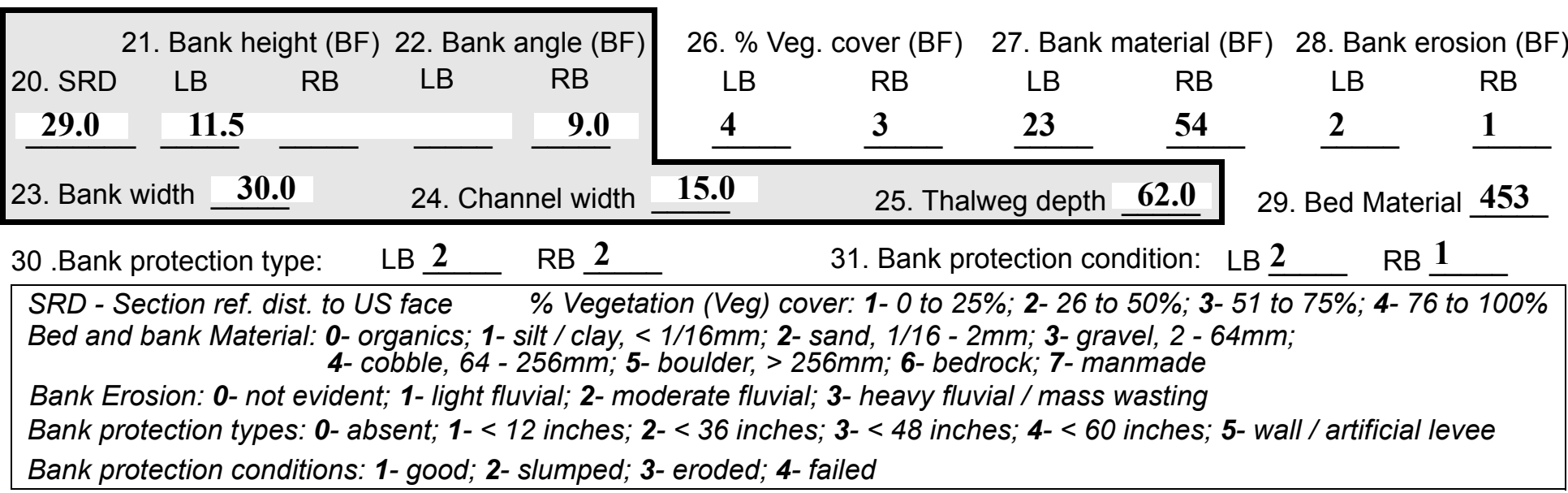

32. Comments (bank material variation, minor inflows, protection extent, etc.):

27. The left bank natural material is sand and gravel and the extensive protection is boulders and cobbles. 30. The right bank protection extends from the end of the wingwall at $6 \mathrm{ft}$ US to $17 \mathrm{ft}$ US. The left bank protection extends from the end of the wingwall at $24 \mathrm{ft}$ US to over $100 \mathrm{ft}$ US to preventing the high bank from eroding. 
36. Point bar extent: $\underline{77}$ feet $\underline{\text { US }}$ (US, UB) to 190 feet $\underline{\text { US }}$ (US, UB, DS) positioned $\underline{\mathbf{3 5}} \%$ LB to 95 \% RB

37. Material: $4 \mathbf{4 3 5}$

38. Point or side bar comments (Circle Point or Side; Note additional bars, material variation, status, etc.):

39. Is a cut-bank present? $\underline{\mathbf{Y}}$ (Yor if $N$ type $c t r l-n c b)$

41. Mid-bank distance: 110

43. Bank damage: 1

42. Cut bank extent: $\mathbf{5 0}$
40. Where? $\underline{\mathbf{L B}}$ (LB or RB) feet $\underline{\mathbf{U S}}$ (US, UB) to $\underline{\mathbf{2 0 0}}$ feet $\underline{\mathbf{U S}}$ (US, UB, DS)

44. Cut bank comments (eg. additional cut banks, protection condition, etc.):

45. Is channel scour present? $\mathbf{N}$ ( $Y$ or if $N$ type ctrl-n cs)

47. Scour dimensions: Length Width -

Depth : -

46. Mid-scour distance: -

48. Scour comments (eg. additional scour areas, local scouring process, etc.):

NO CHANNEL SCOUR

49. Are there major confluences? $\mathbf{Y}$
52. Enters on $\underline{\mathbf{R B}}$
Enters on -
(LB or $R B)$ (LB or $R B)$

( $Y$ or if $N$ type ctrl-n $m c)$

51. Confluence 1: Distance 17

Confluence 2: Distance -

54. Confluence comments (eg. confluence name):

Part of the stream is diverted US into a fire pond which drains back into this stream and forms a minor confluence near the bridge. This small tributary could be called an anabranch.

\section{Under Bridge Channel Assessment}

55. Channel restraint (BF)? LB 2

\begin{tabular}{|cccc}
\hline \multicolumn{2}{|c}{ 56. Height (BF) } & \multicolumn{2}{c}{57 Angle (BF) } \\
LB & RB & LB & RB \\
$\mathbf{1 6 . 0}$ & & $\mathbf{0 . 5}$ &
\end{tabular}

58. Bank width (BF) -

(1- natural bank; 2- abutment; 3- artificial levee)

Bed and bank Material: 0- organics; 1- silt / clay, < 1/16mm; 2- sand, 1/16 - 2mm; 3- gravel, 2 - 64mm; 4- cobble, 64 - 256mm; 5- boulder, > 256mm; 6- bedrock; 7- manmade

Bank Erosion: 0- not evident; 1- light fluvial; 2- moderate fluvial; 3- heavy fluvial / mass wasting

64. Comments (bank material variation, minor inflows, protection extent, etc.):

435 
65. Debris and Ice Is there debris accumulation?

67. Debris Potential $\underline{1}$ (1- Low; 2- Moderate; 3- High)

69. Is there evidence of ice build-up? 2

70. Debris and Ice Comments:

2

There is a small accumulation of scattered debris US.
$(Y$ or $N)$ 66. Where? $\mathbf{Y}$

68. Capture Efficiency 2

(1- Upstream; 2- At bridge; 3-Both)

Ice Blockage Potential $\mathbf{N}$
(1-Low; 2- Moderate; 3- High)

(1-Low; 2- Moderate; 3- High)

\begin{tabular}{|l|c|c|c|c|c|c|c|c|}
\hline Abutments & $\begin{array}{c}\text { 71. Attack } \\
\angle \text { (BF) }\end{array}$ & $\begin{array}{c}\text { 72. Slope } \angle \\
\text { (Qmax) }\end{array}$ & $\begin{array}{c}\text { 73. Toe } \\
\text { loc. (BF) }\end{array}$ & $\begin{array}{c}\text { 74. Scour } \\
\text { Condition }\end{array}$ & $\begin{array}{c}75 . \text { Scour } \\
\text { depth }\end{array}$ & $\begin{array}{c}\text { 76. Exposure } \\
\text { depth }\end{array}$ & 77. Material & 78. Length \\
\hline LABUT & & $\mathbf{0}$ & $\mathbf{9 0}$ & $\mathbf{2}$ & $\mathbf{2}$ & $\mathbf{0}$ & $\mathbf{0 . 3}-$ & $\mathbf{9 0 . 0}$ \\
\hline RABUT & $\mathbf{1 . 3}$ & $\mathbf{1}$ & $\mathbf{2 5}$ & & & $\mathbf{9 0}$ & $\mathbf{2}$ & $\mathbf{2 2 . 5}$ \\
\hline
\end{tabular}

Pushed: $L B$ or RB

Toe Location (Loc.): 0- even, 1- set back, 2- protrudes

Scour cond.: 0- not evident; 1- evident (comment); 2- footing exposed; 3-undermined footing; 4- piling exposed; 5- settled; 6- failed

Materials: 1- Concrete; 2- Stone masonry or drywall; 3- steel or metal; 4- wood

79. Abutment comments (eg. undermined penetration, unusual scour processes, debris, etc.):

3

1

2

1

75. Average thalweg depth is $1 \mathrm{ft}$.

74. The right abutment footing is undermined in several spots from $0.5 \mathrm{ft}$ to as much as $1 \mathrm{ft}$ deep.

76. The left abutment footing is exposed $0.3 \mathrm{ft}$ at the downstream end and $1.3 \mathrm{ft}$ at the upstream end.

77. The right abutment is laid-up stone with a concrete facing. The steel beams sit on top of the stone abutment with the top of the concrete facing $1.25 \mathrm{ft}$ below the low chord.

80. Wingwalls:

$\begin{array}{llll} & & & \\ \text { Exist? Material? } & \text { Scour } & \text { Scour } & \text { Exposure } \\ \text { Condition? } & \text { depth? } & \text { depth? }\end{array}$

USLWW:

USRWW:

DSLWW: 2

DSRWW: Y

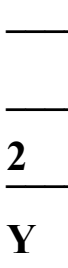

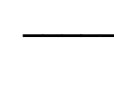

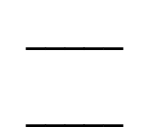

Y

1

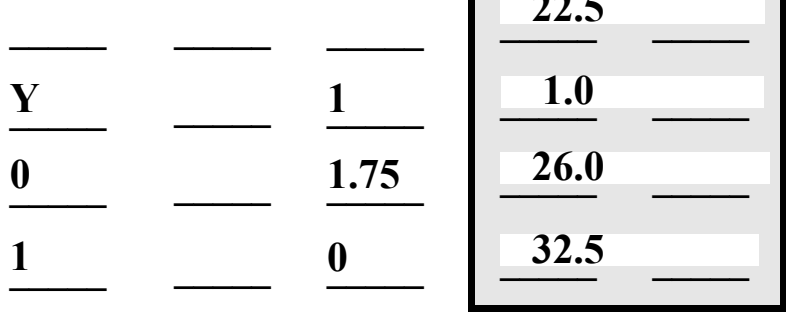

1- Concrete; 2- Stone masonry or drywall; 3- steel or metal; 4- wood

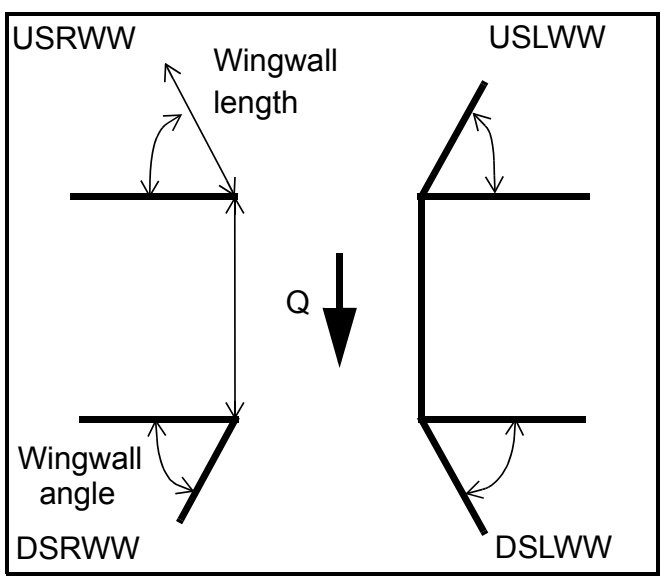

82. Bank / Bridge Protection:

\begin{tabular}{|l|l|l|l|l|l|l|c|c|}
\hline Location & USLWW & USRWW & LABUT & RABUT & LB & RB & DSLWW & DSRWW \\
\hline Type & - & $\mathbf{2}$ & - & $\mathbf{1}$ & $\mathbf{0}$ & $\mathbf{2}$ & $\mathbf{0}$ & $\mathbf{0}$ \\
\hline Condition & - & $\mathbf{0}$ & $\mathbf{Y}$ & $\mathbf{1}$ & - & $\mathbf{1}$ & - & - \\
\hline Extent & $\mathbf{Y}$ & - & $\mathbf{1}$ & $\mathbf{0}$ & - & $\mathbf{1}$ & - & - \\
\hline
\end{tabular}

Bank / Bridge protection types: 0- absent; 1-<12 inches; 2- < 36 inches; 3- < 48 inches; 4- < 60 inches; 
83. Wingwall and protection comments (eg. undermined penetration, unusual scour processes, etc.):

-
-
-
-
-
-
0
-
-
3
1

\section{Piers:}

84. Are there piers? 1 (Y or if $N$ type ctrl-n pr)

\begin{tabular}{|l|r|r|r|r|l|l|l|}
\hline \multirow{2}{*}{$\begin{array}{l}85 . \\
\text { Pier no. }\end{array}$} & \multicolumn{3}{|c|}{ width (w) feet } & \multicolumn{3}{c|}{ elevation (e) feet } \\
\cline { 2 - 8 } & w1 & w2 & w3 & e@w1 & e@w2 & e@w3 \\
\hline Pier 1 & & $\mathbf{7 . 0}$ & $\mathbf{5 . 5}$ & $\mathbf{4 0 . 0}$ & $\mathbf{5 5 . 0}$ & $\mathbf{2 5 . 0}$ \\
\hline Pier 2 & $\mathbf{7 . 0}$ & $\mathbf{6 . 5}$ & - & $\mathbf{1 7 0 . 0}$ & - & - \\
\hline Pier 3 & - & - & - & - & - & - \\
\hline Pier 4 & - & - & - & - & - & - \\
-
\end{tabular}

\begin{tabular}{|l|l|l|l|l|}
\hline Level 1 Pier Descr. & \multicolumn{1}{|c|}{1} & \multicolumn{1}{|c|}{2} & 3 & \multicolumn{1}{|c|}{} \\
\hline 86. Location (BF) & 80. A & and & & - \\
\hline 87. Type & boul- & the & & - \\
\hline 88. Material & der & DS & & - \\
\hline 89. Shape & at & right & & - \\
\hline 90. Inclined? & the & wing & & - \\
\hline 91. Attack $\angle$ (BF) & cor- & wall & & - \\
\hline 92. Pushed & ner & is & & - \\
\hline 93. Length (feet) & - & - & - & - \\
\hline 94. \# of piles & of & unde & & - \\
\hline 95. Cross-members & the & rmin & & - \\
\hline 96. Scour Condition & right & ed & & - \\
\hline 97. Scour depth & abut & abou & N & - \\
\hline 98. Exposure depth & ment & t 1 ft. & - & - \\
\hline
\end{tabular}

LFP, LTB, LB, MCL, MCM, MCR, RB, RTB, RFP

1- Solid pier, 2- column, 3- bent

1-Wood; 2- concrete; 3- metal; 4- stone

1- Round; 2- Square; 3- Pointed

Y-yes; $N$ - no

$L B$ or $R B$

0- none; 1- laterals; 2- diagonals; 3- both

0- not evident; 1- evident (comment);

2- footing exposed; 3- piling exposed;

4- undermined footing; 5- settled; 6- failed 
99. Pier comments (eg. undermined penetration, protection and protection extent, unusual scour processes, etc.):

-
-
-
-
-
-
-
-
-
-

100.

\section{E. Downstream Channel Assessment}

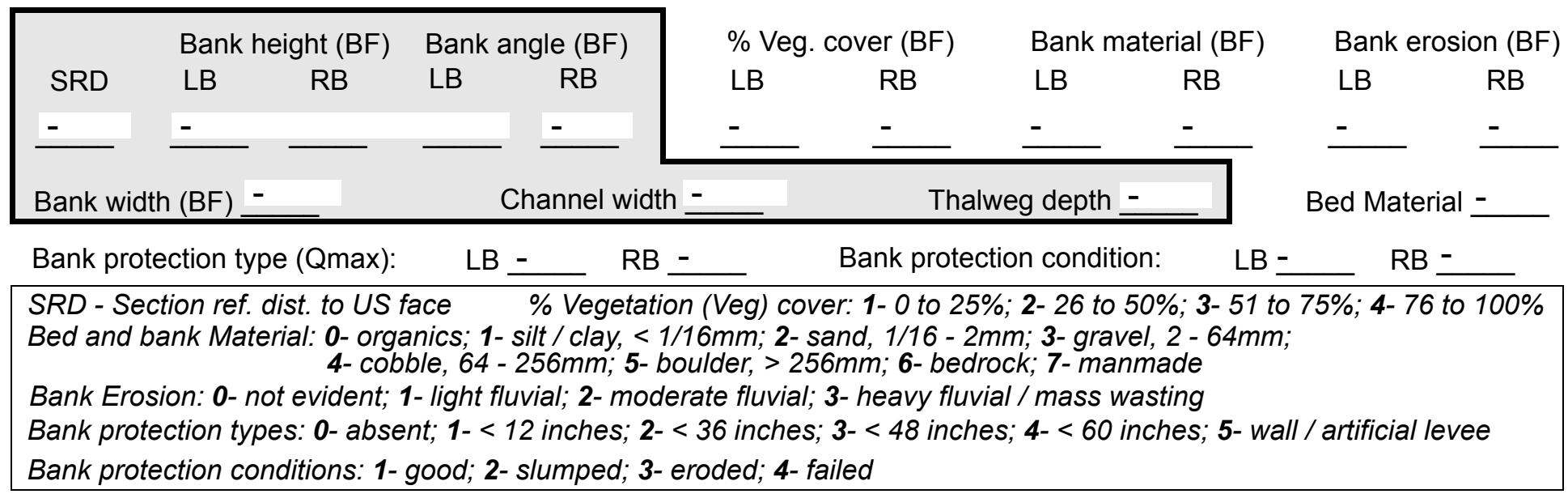

Comments (eg. bank material variation, minor inflows, protection extent, etc.):

-
-
-
-
-
-
-
-
-
-
-
-
-

\section{NO PIERS}

101. Is a drop structure present? (Y or $N$, if $N$ type ctrl-n ds)

102. Distance: - feet

103. Drop: - feet 104. Structure material: (1- steel sheet pile; 2- wood pile; 3- concrete; 4- other)

105. Drop structure comments (eg. downstream scour depth): 
106. Point/Side bar present? (Y or N. if $N$ type ctrl-n pb)Mid-bar distance: $\mathbf{1}$ Mid-bar width: 1 Point bar extent: $\underline{\mathbf{2 3 4 5}}$ feet $\underline{\mathbf{4 3 5}}$ (US, UB, DS) to $\underline{1}$ feet $\underline{\mathbf{2}}$ (US, UB, DS) positioned $\underline{\mathbf{3 4 5}} \%$ LB to $\underline{\mathbf{5}}$ \%RB Material: 3

Point or side bar comments (Circle Point or Side; note additional bars, material variation, status, etc.):

1

2

On the left bank there are no trees from the bridge face to $32 \mathrm{ft}$ DS, then the vegetation cover increases to $51 \%$ to $75 \%$. The right bank has no trees, just shrubs, for $68 \mathrm{ft}$ DS then it also increases to $51 \%$ to $75 \%$.

Is a cut-bank present? Th (Y or if $N$ type ctrl-n $c b)$ Where? e (LB or RB) Mid-bank distance: left Cut bank extent: bank feet at (US, UB, DS) to the feet exit (US, UB, DS)

Bank damage: sec (1- eroded and/or creep; 2- slip failure; 3- block failure)

Cut bank comments (eg. additional cut banks, protection condition, etc.):

tion is sand and gravel. A cobble and boulder stone wall extends along the top of the bank beginning at $24 \mathrm{ft}$ DS and continuing to $110 \mathrm{ft}$ DS. Three large, type-2 boulders have been placed between the bridge and $21 \mathrm{ft}$ DS on the left bank. The right bank protection extends from the end of the DS right wingwall to $32 \mathrm{ft}$ DS.

Is channel scour present? ( $Y$ or if $N$ type ctrl-n cs)

Mid-scour distance:

Scour dimensions: Length Width Depth:

Positioned $\%$ LB to $\% \mathrm{RB}$

Scour comments (eg. additional scour areas, local scouring process, etc.):

$\mathbf{N}$

NO DROP STRUCTURE

Are there major confluences? ( $Y$ or if $N$ type ctrl-n $m c)$

How many?

Confluence 1: Distance Enters on (LB or $R B)$

Type

Confluence 2: Distance $\mathbf{Y}$ Enters on $\underline{110}$ (LB or RB)

Type $\underline{\mathbf{2 2}}$ (1- perennial; 2- ephemeral)

Confluence comments (eg. confluence name):

4

US

\section{F. Geomorphic Channel Assessment}

107. Stage of reach evolution $\mathbf{1 5 0}$

1- Constructed

2- Stable

3- Aggraded

4- Degraded

5- Laterally unstable

6- Vertically and laterally unstable 
108. Evolution comments (Channel evolution not considering bridge effects; See HEC-20, Figure 1 for geomorphic descriptors):

DS

O

60

435

This point bar is mostly gravel from the bridge to $28 \mathrm{ft}$ DS and then is cobbles and boulders further DS.

$\mathbf{Y}$

RB

105

31

DS 


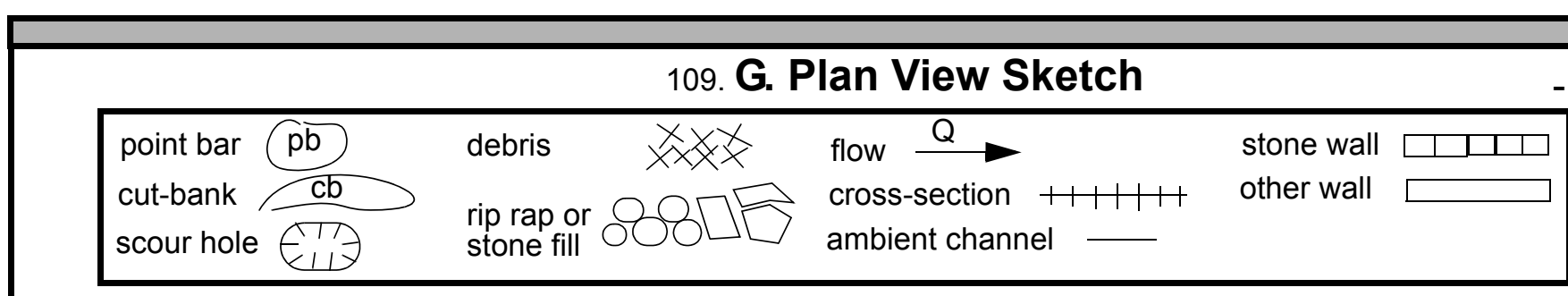


APPENDIX F:

SCOUR COMPUTATIONS 


\begin{tabular}{|c|c|c|c|}
\hline Structure Number: TOWNTH00290037 & & Town: & TOWNSHEND \\
\hline $\begin{array}{lcl}\text { Road Number: } & \text { TH } 29\end{array}$ & & County: & WINDHAM \\
\hline Initials RLB & Checked: & MAI & \\
\hline Analysis of contraction scour, live & bed or $\mathrm{cl}$ & lear wa & \\
\hline $\begin{array}{l}\text { Critical Velocity of Bed Material } \\
\text { VC=11.21*y1^0.1667*D50^0.33 with Ss } \\
\text { (Richardson and Davis, 1995, p. 28, }\end{array}$ & $\begin{array}{l}\text { converted } \\
=2.65 \\
\text { eq. } 16)\end{array}$ & to Engl & sh units) \\
\hline Approach Section & & & \\
\hline Characteristic & $100 \mathrm{yr}$ & $500 \mathrm{yr}$ & other $Q$ \\
\hline Total discharge, cfs & 3390 & 4600 & 1770 \\
\hline Main Channel Area, ft2 & 603 & 643 & 477 \\
\hline Left overbank area, ft2 & 56 & 106 & 0 \\
\hline Right overbank area, ft2 & 343 & 434 & 86 \\
\hline Top width main channel, ft & 69 & 69 & 67 \\
\hline Top width L overbank, ft & 79 & 90 & 0 \\
\hline Top width $\mathrm{R}$ overbank, ft & 154 & 160 & 108 \\
\hline D50 of channel, ft & 0.2298 & 0.2298 & 0.2298 \\
\hline D50 left overbank, ft & -- & -- & -- \\
\hline D50 right overbank, ft & -- & -- & -- \\
\hline $\mathrm{Y}_{1}$, average depth, MC, ft & 8.7 & 9.3 & 7.1 \\
\hline Y1, average depth, LOB, ft & 0.7 & 1.2 & ERR \\
\hline y1, average depth, ROB, ft & 2.2 & 2.7 & 0.8 \\
\hline Total conveyance, approach & 73074 & 86914 & 43309 \\
\hline Conveyance, main channel & 60817 & 67682 & 41936 \\
\hline Conveyance, LOB & 1332 & 3533 & 0 \\
\hline Conveyance, ROB & 10925 & 15698 & 1372 \\
\hline Percent discrepancy, conveyance & 0.0000 & 0.0012 & 0.0023 \\
\hline Qm, discharge, MC, cfs & 2821.4 & 3582.1 & 1713.9 \\
\hline Ql, discharge, LOB, Cfs & 61.8 & 187.0 & 0.0 \\
\hline Qr, discharge, ROB, Cfs & 506.8 & 830.8 & 56.1 \\
\hline Vm, mean velocity $\mathrm{MC}$, ft/s & 4.7 & 5.6 & 3.6 \\
\hline $\mathrm{VI}$, mean velocity, LOB, ft/s & 1.1 & 1.8 & ERR \\
\hline Vr, mean velocity, $\mathrm{ROB}$, ft/s & 1.5 & 1.9 & 0.7 \\
\hline Vc-m, crit. velocity, $M C$, ft/s & 9.9 & 10.0 & 9.5 \\
\hline VC-1, crit. velocity, LOB, ft/s & $\mathrm{ERR}$ & ERR & ERR \\
\hline Vc-r, crit. velocity, ROB, ft/s & ERR & ERR & ERR \\
\hline Result: & & & \\
\hline Live-bed(1) or Clear-Water(0) Contr & action $\mathrm{Scc}$ & our? & \\
\hline Main Channel & 0 & 0 & 0 \\
\hline Left Overbank & $\mathrm{N} / \mathrm{A}$ & $\mathrm{N} / \mathrm{A}$ & $\mathrm{N} / \mathrm{A}$ \\
\hline Right Overbank & $\mathrm{N} / \mathrm{A}$ & $\mathrm{N} / \mathrm{A}$ & $\mathrm{N} / \mathrm{A}$ \\
\hline
\end{tabular}


Clear water Contraction Scour in MAIN CHANNEL

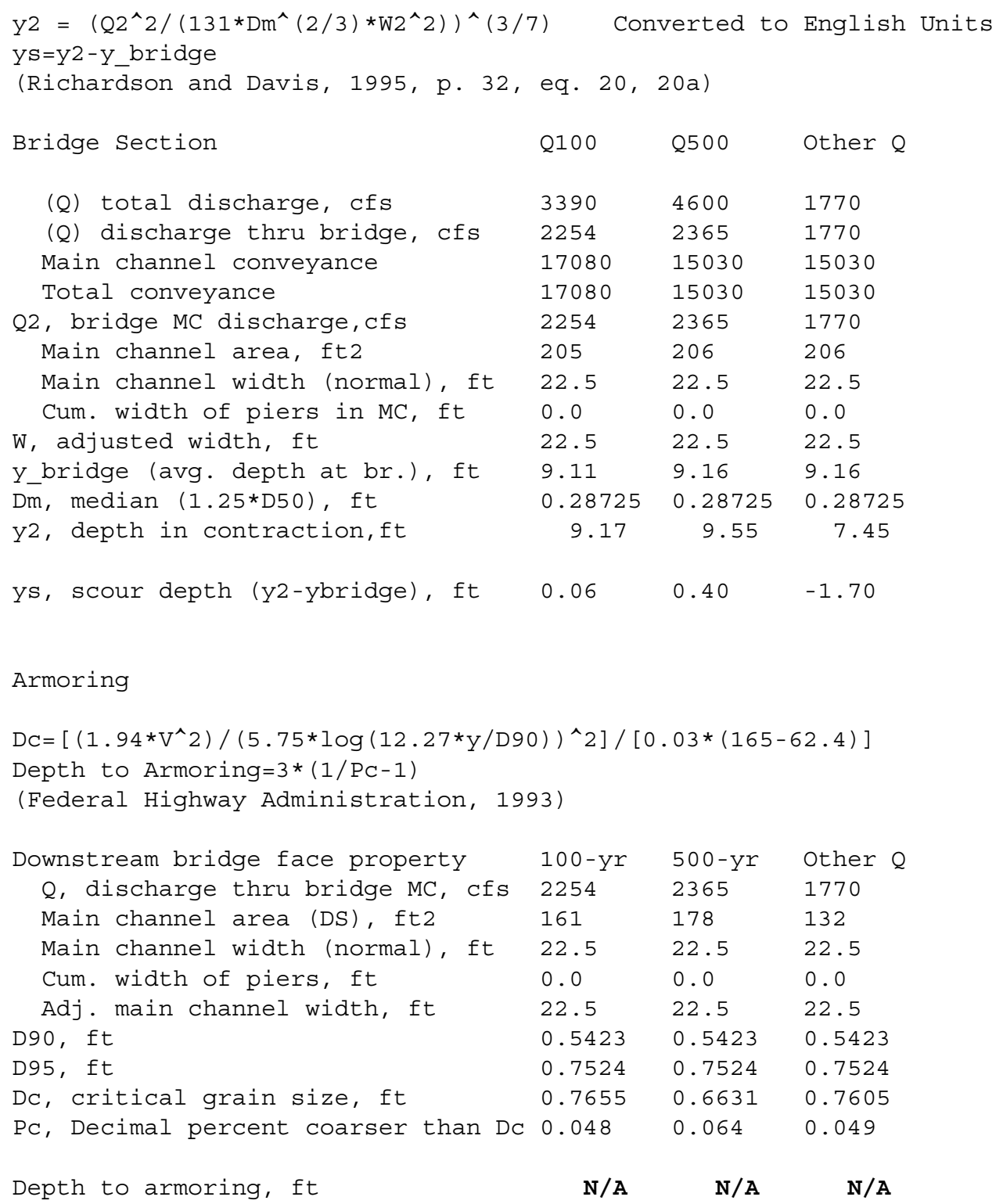




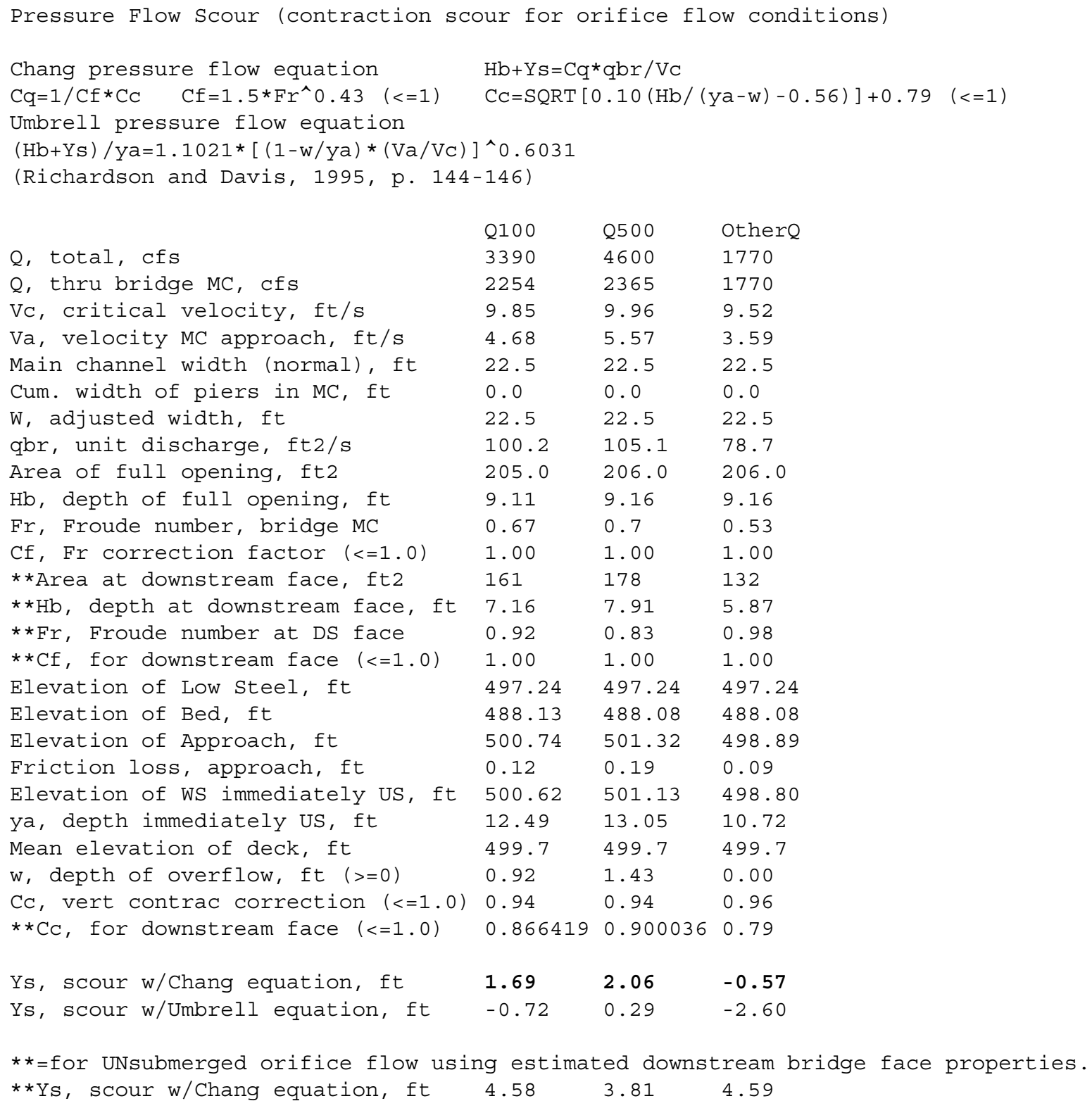


**Ys, scour w/Umbrell equation, ft $1.23 \quad 1.53 \quad 0.69$

In UNsubmerged orifice flow, an adjusted scour depth using the Laursen equation results and the estimated downstream bridge face properties can also be computed (ys=y2-ybridgeDs)

WSET at downstream face, ft 9.17

Depth at downstream face, ft

Ys, depth of scour (Laursen), ft
495.26

7.16

2.01
9.55

7.91

1.64
7.45

493.96

5.87

1.59

Abutment scour

Froehlich's Abutment Scour

$\mathrm{Ys} / \mathrm{Y} 1=2.27 * \mathrm{~K} 1 * \mathrm{~K} 2 *\left(\mathrm{a}^{\prime} / \mathrm{Y} 1\right)^{\wedge} 0.43 * \mathrm{Fr} 1 \wedge 0.61+1$

(Richardson and Davis, 1995, p. 48, eq. 28)

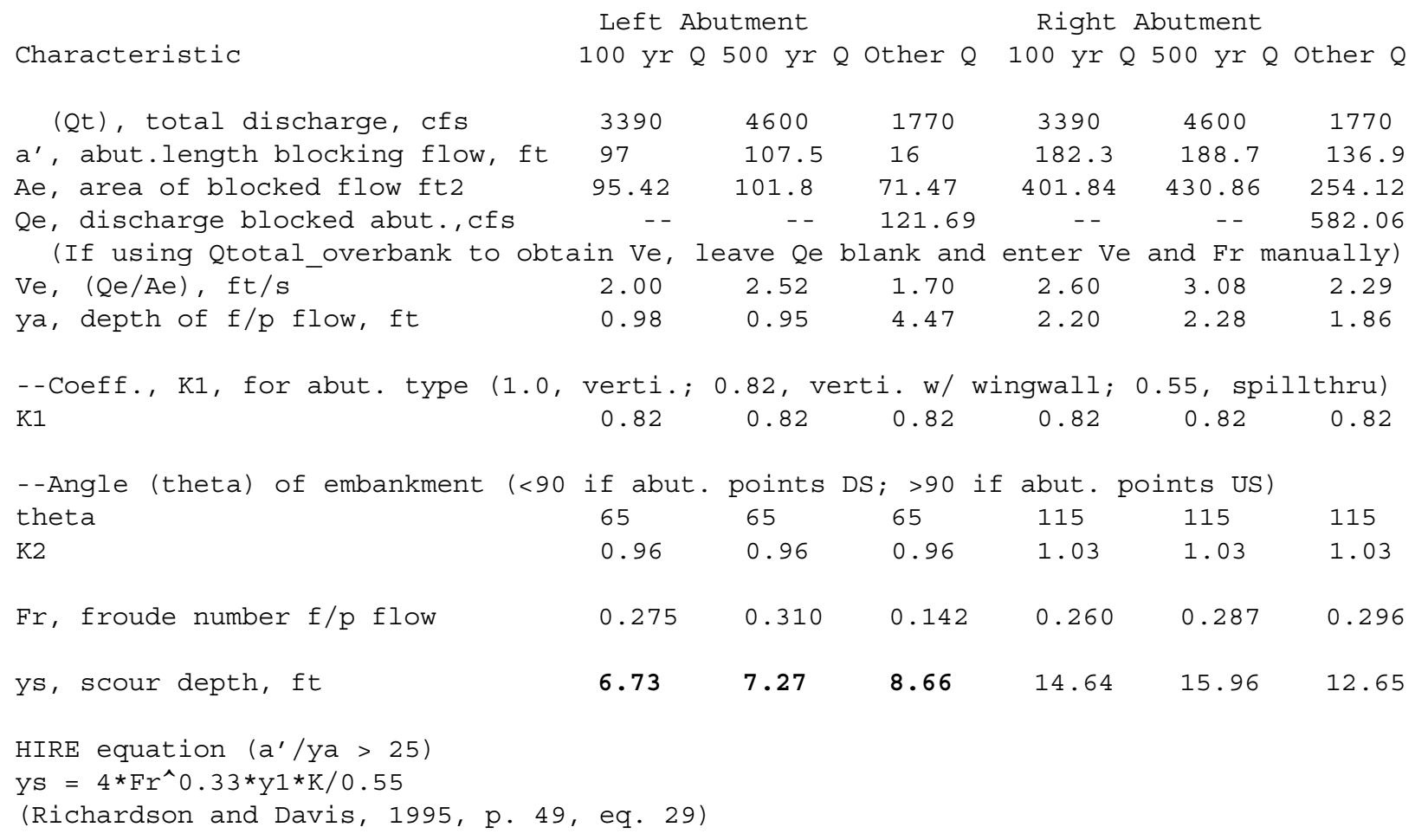




\begin{tabular}{|c|c|c|c|c|c|c|}
\hline$a^{\prime}$ (abut length blocked, ft) & 97 & 107.5 & 16 & 182.3 & 188.7 & 136.9 \\
\hline y1 (depth f/p flow, ft) & 0.98 & 0.95 & 4.47 & 2.20 & 2.28 & 1.86 \\
\hline$a^{\prime} / y^{1}$ & 98.61 & 113.52 & 3.58 & 82.70 & 82.64 & 73.75 \\
\hline Skew correction (p. 49, fig. 16) & 0.92 & 0.92 & 0.92 & 1.06 & 1.06 & 1.06 \\
\hline Froude no. f/p flow & 0.28 & 0.31 & 0.14 & 0.26 & 0.29 & 0.30 \\
\hline Ys w/ corr. factor K1/0.55: & 4.28 & 4.29 & ERR & 10.85 & 11.62 & 9.54 \\
\hline vertical w/ ww's & $\begin{array}{l}4.28 \\
3.51\end{array}$ & $\begin{array}{l}4.29 \\
3.52\end{array}$ & $\begin{array}{l}\text { ERR } \\
\mathrm{ERR}\end{array}$ & 8.90 & 9.52 & 7.82 \\
\hline spill-through & 2.36 & 2.36 & ERR & 5.97 & 6.39 & 5.25 \\
\hline Abutment riprap Sizing & & & & & & \\
\hline Isbash Relationship & & & & & & \\
\hline $\begin{array}{l}\mathrm{D} 50=\mathrm{Y}^{*} \mathrm{~K}^{*} \mathrm{Fr} \mathrm{r}^{\wedge} 2 /(\mathrm{Ss}-1) \text { and } \mathrm{D} 50=\mathrm{Y}^{*} \mathrm{~K}^{*} \\
\text { (Richardson and Davis, 1995, p112 }\end{array}$ & 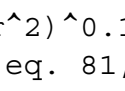 & $(S s-1)$ & & & & \\
\hline Characteristic & Q100 & Q500 & Other $Q$ & Q100 & Q500 & Other Q \\
\hline Fr, Froude Number & 0.92 & 0.83 & 0.98 & 0.92 & 0.83 & 0.98 \\
\hline$y$, depth of flow in bridge, ft & 7.16 & 7.91 & 5.87 & 7.16 & 7.91 & 5.87 \\
\hline Median Stone Diamete & : left & utment & & right & abutment, & ft \\
\hline Fr $<=0.8$ (vertical abut.) & ERR & ERR & ERR & ERR & ERR & ERR \\
\hline Fr>0.8 (vertical abut.) & 2.93 & 3.14 & 2.44 & 2.93 & 3.14 & 2.44 \\
\hline
\end{tabular}

